\title{
Field Observations on Neotropical Treeboas of the Genus Corallus (Squamata: Boidae)
}

\author{
César L. Barrio-Amorós \\ Fundación AndígenA, Apartado Postal 210, Mérida, Venezuela (cesarlba@yahoo.com) \\ (Current address: Doc Frog Expeditions, Uvita de Osa, Costa Rica) \\ Photographs by the author except where indicated.
}

A a wildlife guide, I have had many opportunities to observe Neotropical treeboas of the genus Corallus. Such opportunities arose especially during my tours and explorations in Venezuela (1994-2011), but also in Costa Rica (2011-present), Ecuador (June-July 2014), and Peru (AprilJune 2004). The majority of my observations (three of $C$. caninus, 12 of $C$. hortulanus and 167 of C. ruschenbergerii) were concentrated from 2000 to 2011, when I was most active exploring different areas of Venezuela and went frequently to the Llanos and the Maracaibo Basin leading nature tours. In each account that follows I provide ecological, distributional, and anecdotal information about these treeboas, highlighting some novel observations not reported by Henderson (2015).

\section{Corallus annulatus}

Annulated or Ringed Treeboa

My only experience with this species consists of three encounters, all in Caribbean Costa Rica. One was adjacent to a shallow stream at Pandora, Limón, where a large individual was foraging actively on a slender stem about $2 \mathrm{~m}$ high (Fig. 1). The second was along another stream at Reserva Privada La Ceiba, Manzanillo, where a very thin subadult of about 80 $\mathrm{cm}$ slithered about $4 \mathrm{~m}$ above the water. The third was an adult discovered during the day on the roof of a house at forest edge in Matina, Limón.

\section{Corallus batesii}

\section{Amazon Basin Emerald Treeboa}

During a stay of several days at $\mathrm{km} 34$ on the road from Tarapoto to Yurimaguas, Peru, at Rainer Schulte's concession (INIBICO), I saw one very thin and apparently sick $C$. batesii about $100 \mathrm{~cm}$ long on a dirt road very early in the morning. We collected it to take photos and observe it for a while, but it died after two days. During those last days, it remained motionless. I was unable to dissect the specimen to determine the cause of its death.

\section{Corallus blombergii \\ Blomberg's Treeboa}

While herping with companions from Tropical Herping at the San Lorenzo Lodge, Provincia Esmeraldas, Ecuador, we observed three $C$. blombergii on a single night (29 May 2014). One was on an old wooden gate about $1.6 \mathrm{~m}$ high. Another (Fig. 2), encountered along a rainforest stream, was collected

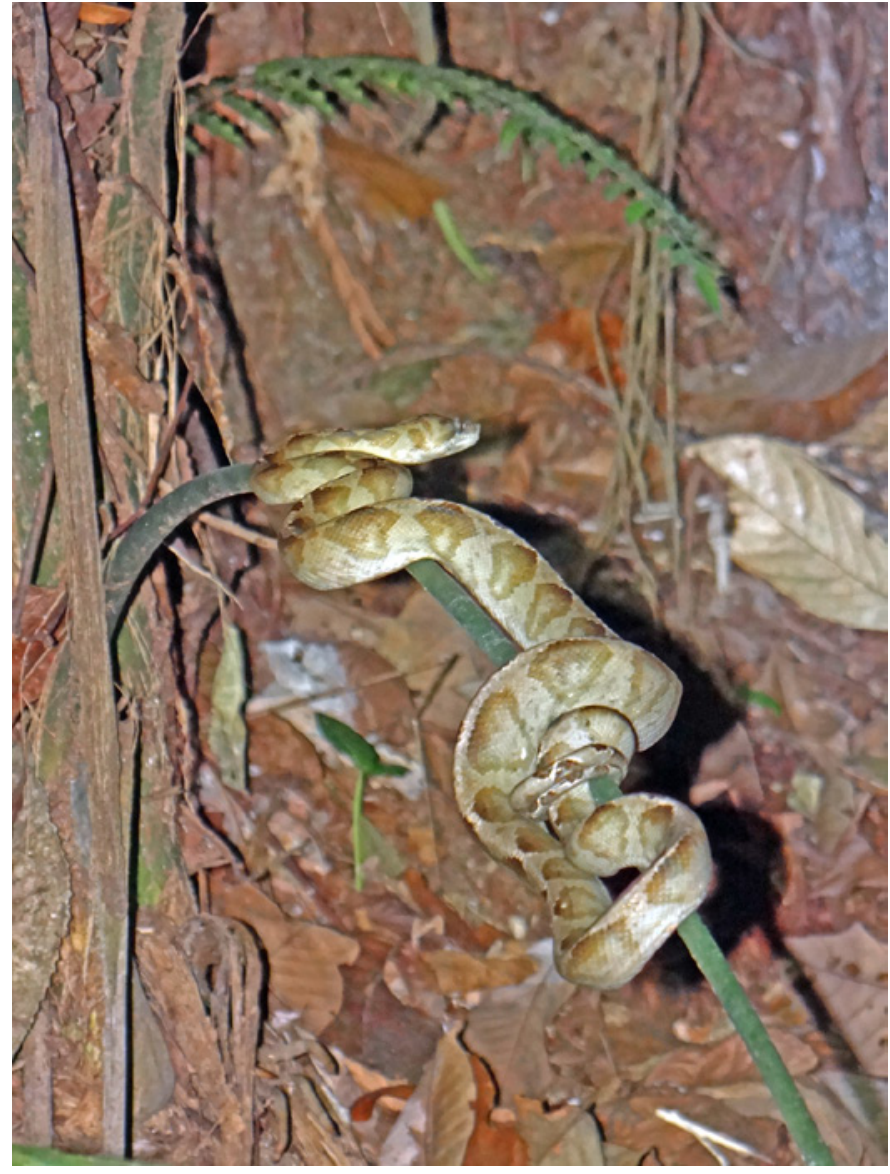

Fig. 1. An Annulated Treeboa (Corallus annulatus) on a branch hanging over a stream in Pandora, Limón Province, Costa Rica. 


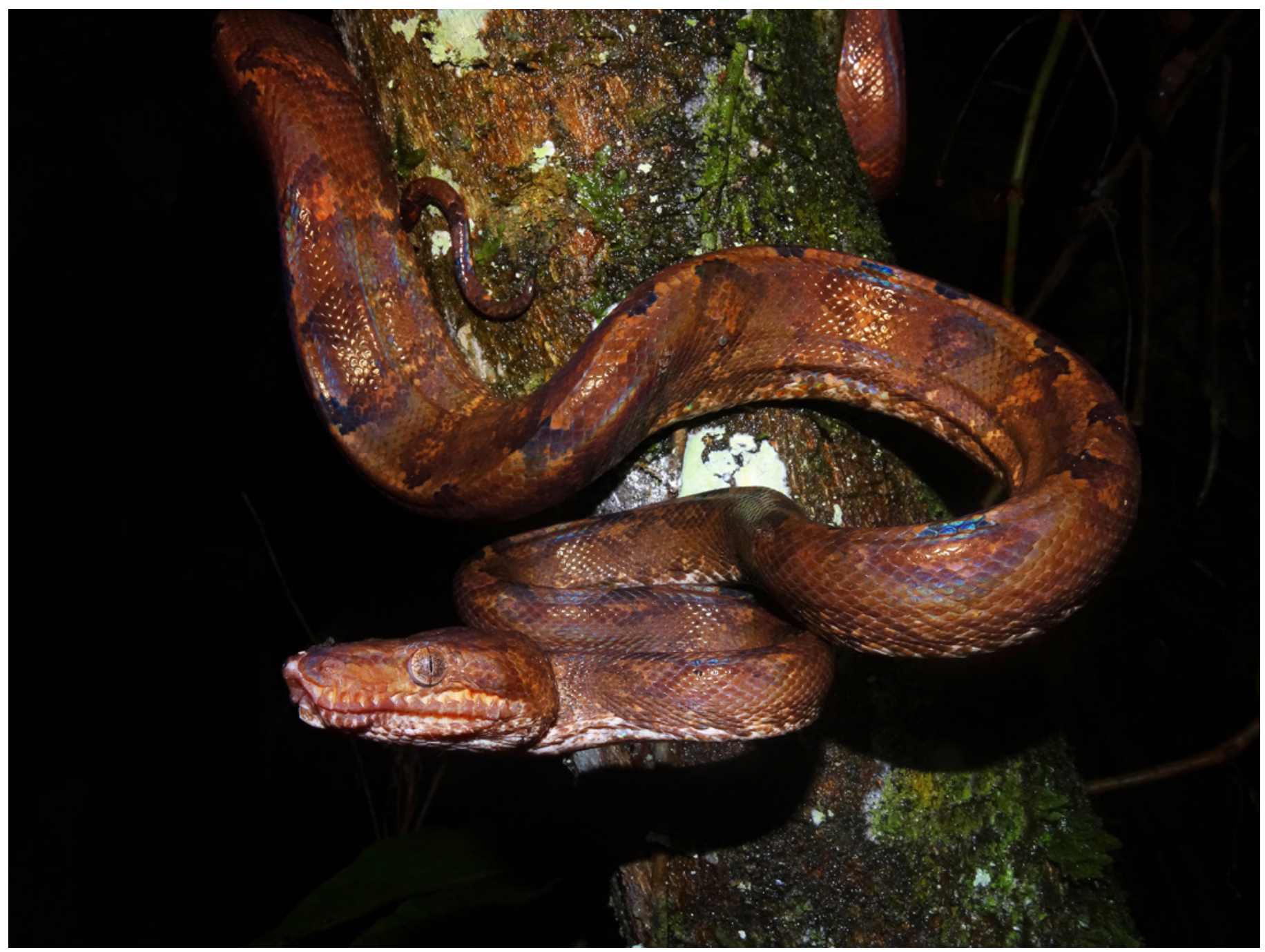

Fig. 2. A Blomberg's Treeboa (Corallus blombergii) from San Lorenzo, Esmeraldas, Ecuador.

for photographs and then released. It escaped by climbing the vertical trunk of a young tree in a concertina fashion. The third was about $8 \mathrm{~m}$ high in rainforest along a stream. These observations contradict the statement that $C$. blombergii is a rare species (Henderson 2015). As with almost all species, it can be common in appropriate conditions (the only exception in the genus Corallus appears to be Cropani's Treeboa (C. cropanii).

\section{Corallus caninus \\ Emerald Treeboa}

I personally have found only three Corallus caninus. Two of them were at Triunfo, a lowland site in the northeastern versant of Sierra de Lema (Barrio-Amorós et al. 2011). On 29 March 1997, after two months of fieldwork, I found one female $C$. caninus about $1.20 \mathrm{~m}$ in length on the ground at the airstrip at about $1800 \mathrm{~h}$. The forest edge was just a few meters away. That was not an isolated case, as my colleague Daniel Calcaño found several dead individuals on the road north of Sierra de Lema. Another was found by my com- panion Freddy Mendoza, also at Triunfo. It was also at one end of the airstrip at night at around $1.50 \mathrm{~m}$ high in a bush in a forest-edge situation. My last personal observation was at night in evergreen rainforest on the trail close to El Pauji heading to Santa Elena de Uairén in Estado Bolivar. I spent 10 days exploring the area, and on one of the nights, searching the canopy (around $20 \mathrm{~m}$ high) with my headlamp, I saw the eyeshine of a moving snake. It was not easy to follow as it disappeared intermittently, probably due to its height in the canopy and that it was heading into the denser forest. I took a photograph with a 400-mm telephoto lens and a potent flash, but the distance made it difficult to focus sharply. However, the green dorsum and yellow belly of the snake were clear. People from Bolivar state know it as "zarzillo," which means earring, for the way it can be coiled. They also refer in the same way to the Green Jararaca (Bothrops bilineatus), a green venomous viperid snake.

Curiously, I had been living in Puerto Ayacucho (northwestern Amazonas state) for a year in 1998, and even though it is the northern edge of the Amazon-Orinoco rainforest, I 
did not see or hear anyone confirm the presence of $C$. caninus. Some friends, like the brothers Renato and Roberto Mattei, long-time butterfly collectors interested in snakes and who knew the area, never saw or heard of $C$. caninus. The closest report in Amazonas state is at the southernmost edge of Venezuela at the Neblina base camp (McDiarmid and Paolillo 1988; Henderson 2015).

I suffered a bite on my left hand from a captive individual (1.45 $\mathrm{m}$ in length). The large teeth of these snakes are capable of penetrating to the bones of the hand, and they did. The pain was so intense when the teeth reached the metacarpals that I felt as if I was going to black out. The lacerations were deep and I bled for at least an hour. I used a handkerchief for pressure until I arrived at the emergency entrance of a private clinic in Caracas. Fortunately, the teeth did not damage any important artery or vein.

\section{Corallus hortulanus}

\section{Amazon or Garden Treeboa}

Corallus hortulanus is one of the most polychromatic of boas (the Grenada Bank Treeboa, C. grenadensis, being the other), and individuals of almost all possible colors are known from throughout the species' wide range. Henderson (2015) illustrated several patterns but made no attempt to classify them. Of 12 snakes I have seen in Venezuela, one was pale brownish with a few vertebral X-shaped marks, three were yellow (two from the area around Gavilán, near Puerto Ayacucho, Estado Amazonas, Fig. 3; another from the Casiquiare, Amazonas), eight had more-or-less contrasting ellipsoidsal patterns over a

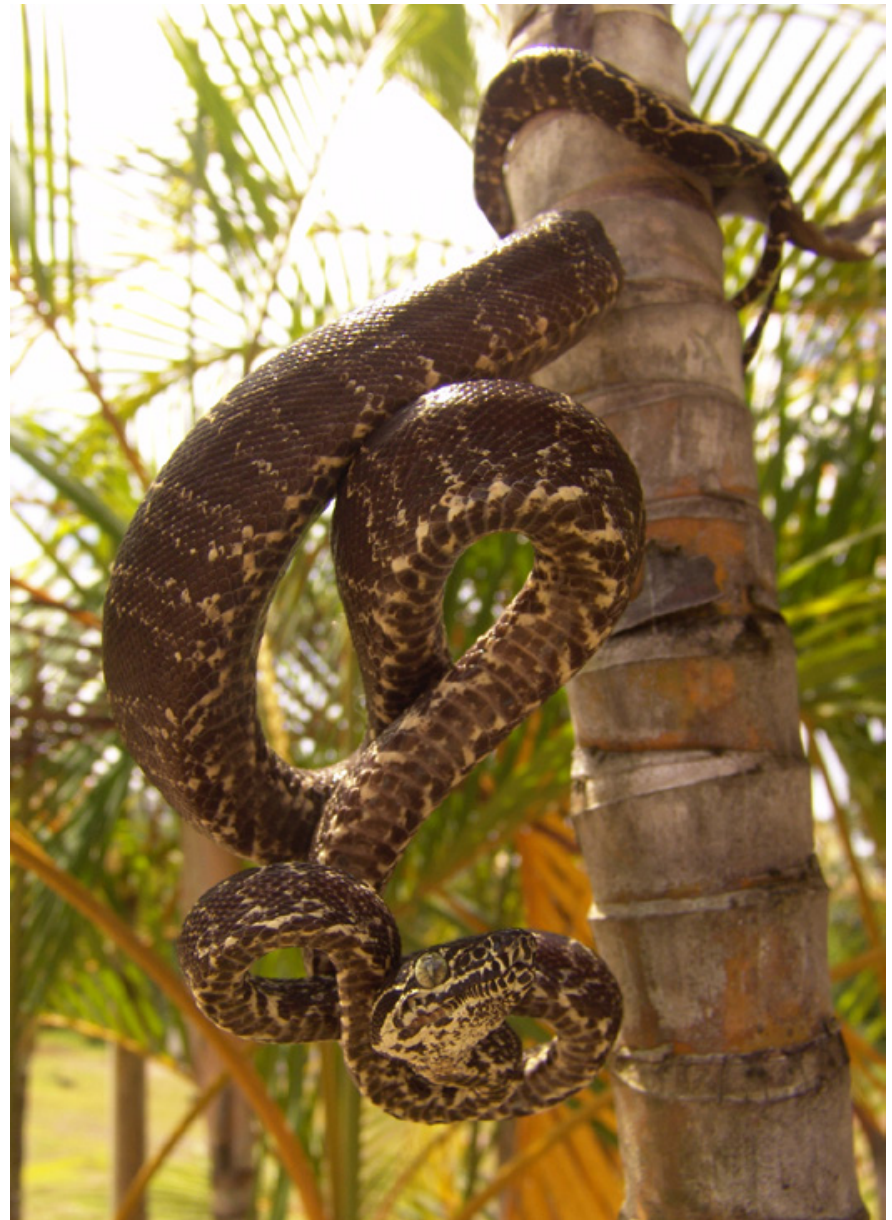

Fig. 4. An Amazon Treeboa (Corallus hortulanus) with an ellipsoidal pattern from Gavilán, Puerto Ayacucho, Amazonas, Venezuela.

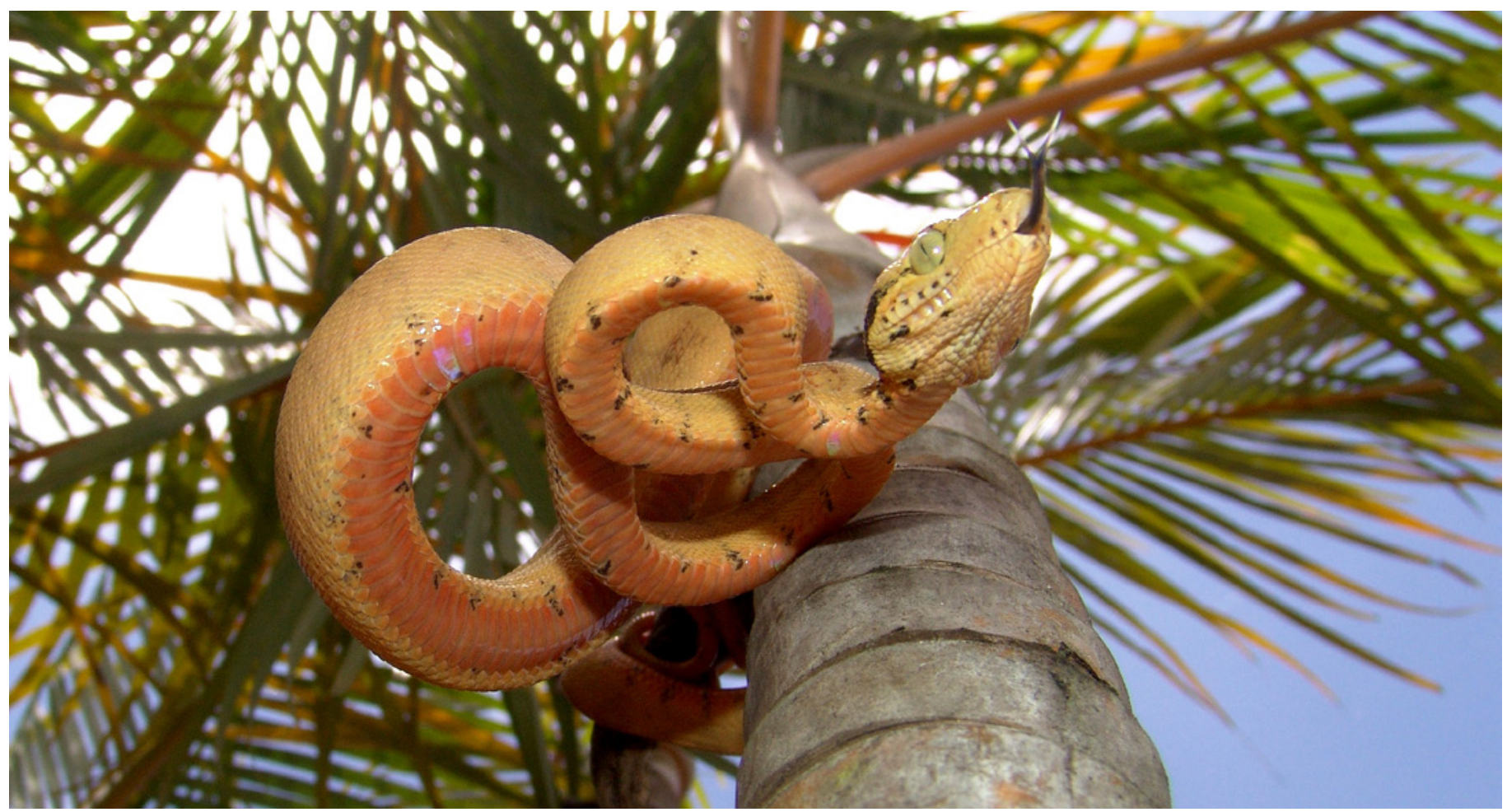

Fig. 3. A yellow-phase Amazon Treeboa (Corallus hortulanus) from Gavilán, Puerto Ayacucho, Amazonas, Venezuela. 
brown or gray ground color (one from Cuyuni river, Estado Bolivar, Fig. 103 in Henderson 2015; one from the northern slopes of the Sierra de Lema, Estado Bolívar; four from around Puerto Ayacucho, Amazonas, at Gavilan, Fig. 4; one from the Casiquiare, Amazonas, and one from Hato San Leonardo, Estado Apure - the first report of this species from that state north of the Orinoco River, Fig. 5 - see also below).

In August 1995, I was taking pictures of an adult male near Puerto Ayacucho when the boa "balled" around a branch (Fig. 6), remained quiet, and made no attempt to escape.

A captive female from an unknown locality in southern Venezuela in the Bararida Zoo (Barquisimeto, Estado Lara) gave birth to seven neonates. Three offspring differed completely in color (pale grey, red-orange, and pale brown) but all had small inverted parenthesis-like or irregularly distributed half-parenthesis-like markings. Flank patterns consisted of diffused large to small diamond-like or ellipsoidal marks. The irises of each snake matched the dorsal ground color (Fig. 7).

During an expedition along the Casiquiare tributary between the Orinoco and the Negro Rivers in southern

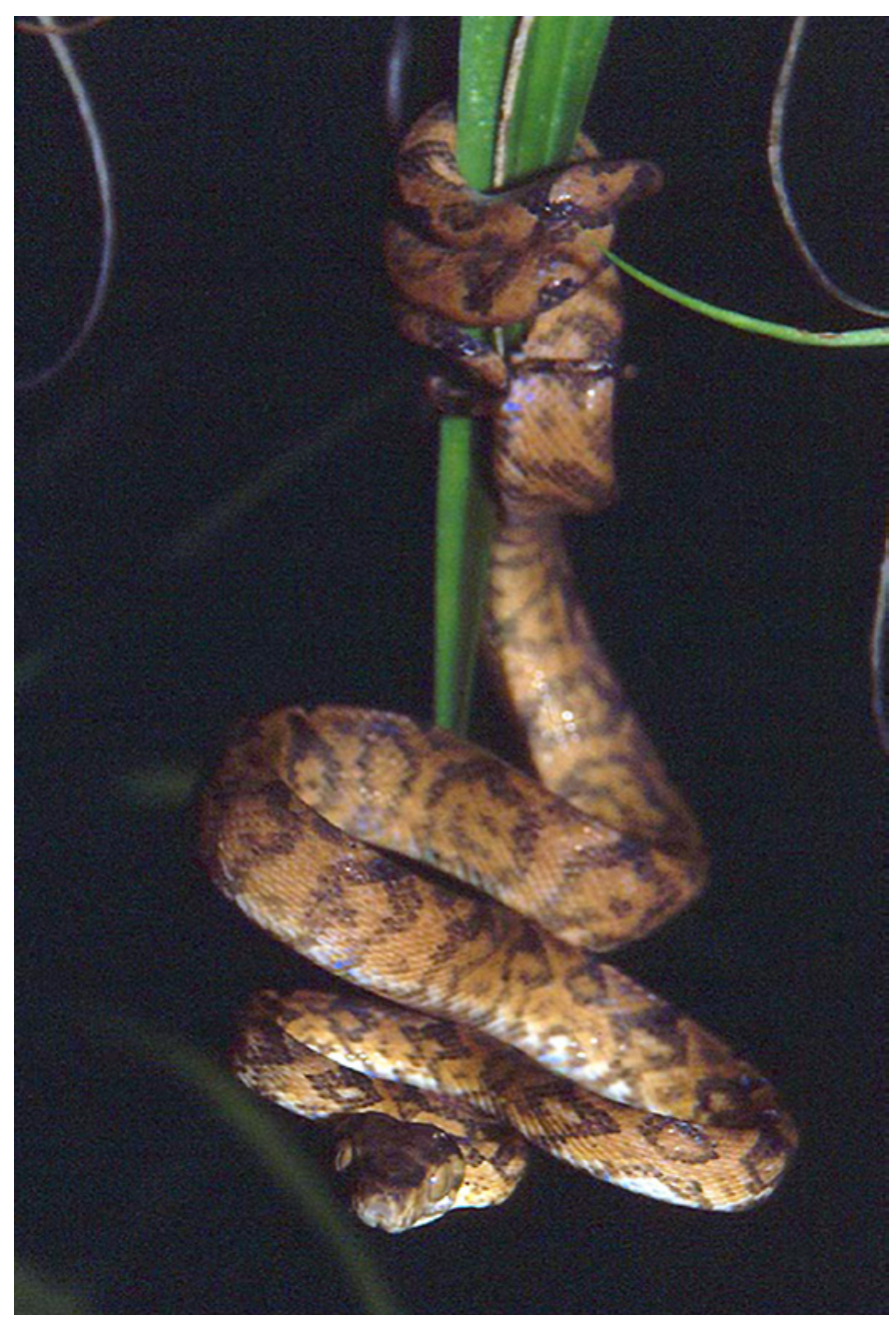

Fig. 5. An Amazon Treeboa (Corallus hortulanus) from Hato San Leonardo, Capanaparo River, Apure, Venezuela; the first record of this species in Apure State.

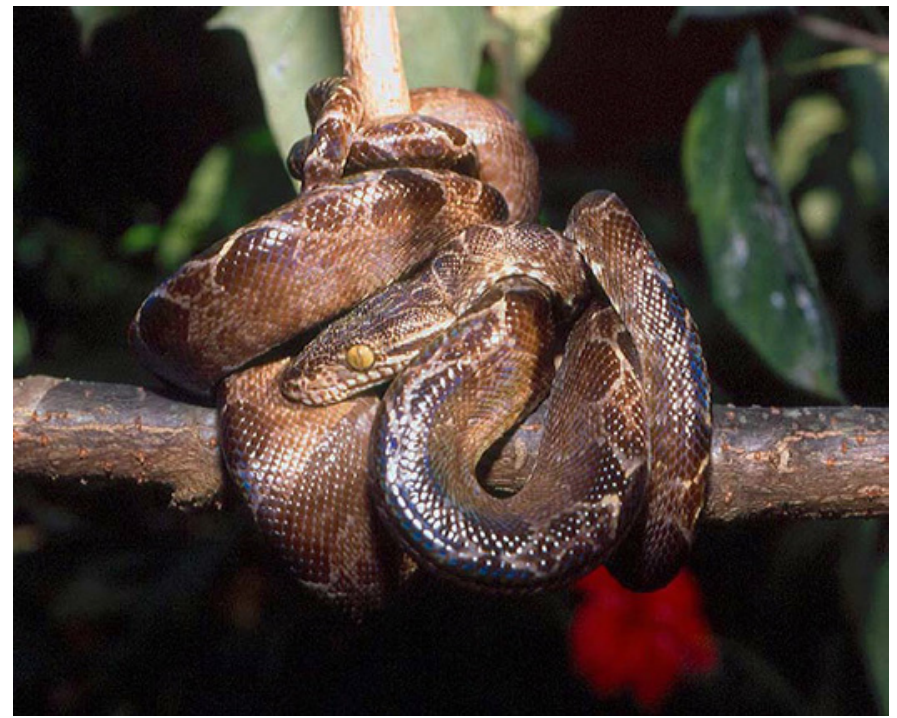

Fig. 6. An Amazon Treeboa (Corallus hortulanus) from Tobogan de la Selva, Puerto Ayacucho, Amazonas, Venezuela, in a defensive "ball" position.

Amazonas state (December 1998), I could see many eyeshines in primary rainforest from our boat. I collected two for pictures. Unfortunately, those old slides were damaged by fungi. One specimen had a contrasting ellipsoidal pattern, the other was yellow. Both were in low vegetation (less than $2 \mathrm{~m}$ ) hanging over the river.

One of my first encounters with a Corallus happened in July 1997 at Hato San Leonardo, estado Apure, on the northern shore of the Capanaparo River. The Capanaparo is one of the southernmost rivers in Los Llanos and directly connected with the rainforests of the Orinoco and their fauna, explaining why many typical Amazonian species have been found in that general area. These include the Smooth-sided Toad (Rhaebo guttatus, Barrio-Amorós et al. 2001); the Bigheaded Amazon River Turtle (Peltocephalus dumerilianus; Pritchard and Trebbau 1984), and Herrmann's Watersnake (Hydrodynastes bicinctus, Natera et al. 2015), but this is the first report of $C$. hortulanus north of the Orinoco in Apure state (Fig. 5).

Corallus hortulanus is common in the Parque Nacional Yasuni, Ecuador. In only one week, I found seven individuals at night without searching specifically for them. Some were in the main building and some even entered the dormitories. One had a contrasting ellipsoid gray pattern with pinkish edges (Fig. 8) and another was almost uniform pale brown with a few small middorsal X-shaped marks (Fig. 9).

\section{Corallus ruschenbergerii \\ Ruschenberger's Treeboa Venezuelan Llanos}

Pattern.-As described by Henderson (2015), the typical color pattern in the Venezuelan Llanos is light brown to yellow with middorsal or lateral dark brown diamonds; however, the dark color of the diamonds can be fused in old, large individu- 


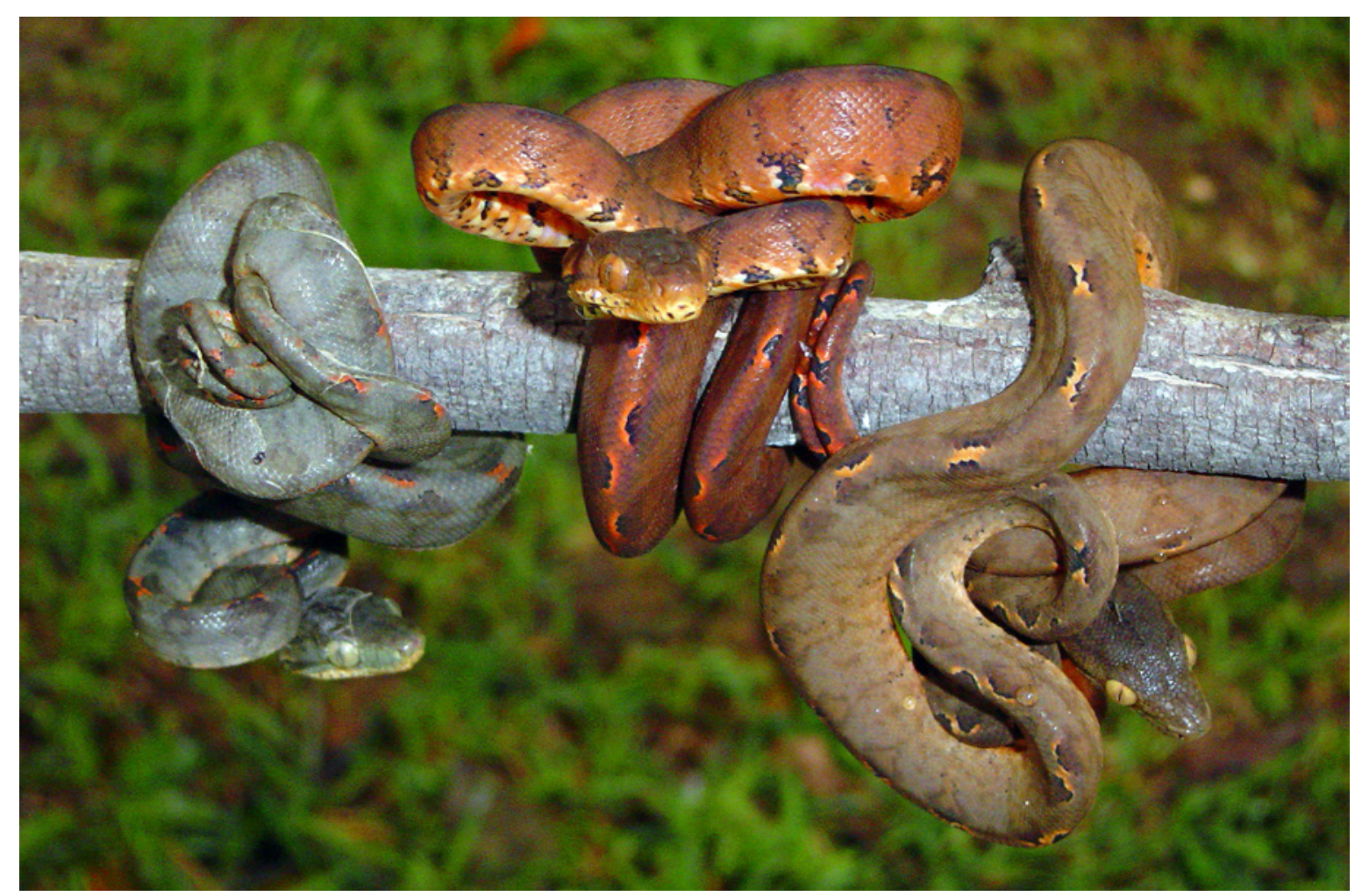

Fig. 7. Three distinct patterns in seven neonatal Amazon Treeboas (Corallus hortulanus) from the same litter; the mother is from an unknown locality in Venezuela; Bararida Zoo, Barquisimeto, Lara, Venezuela.

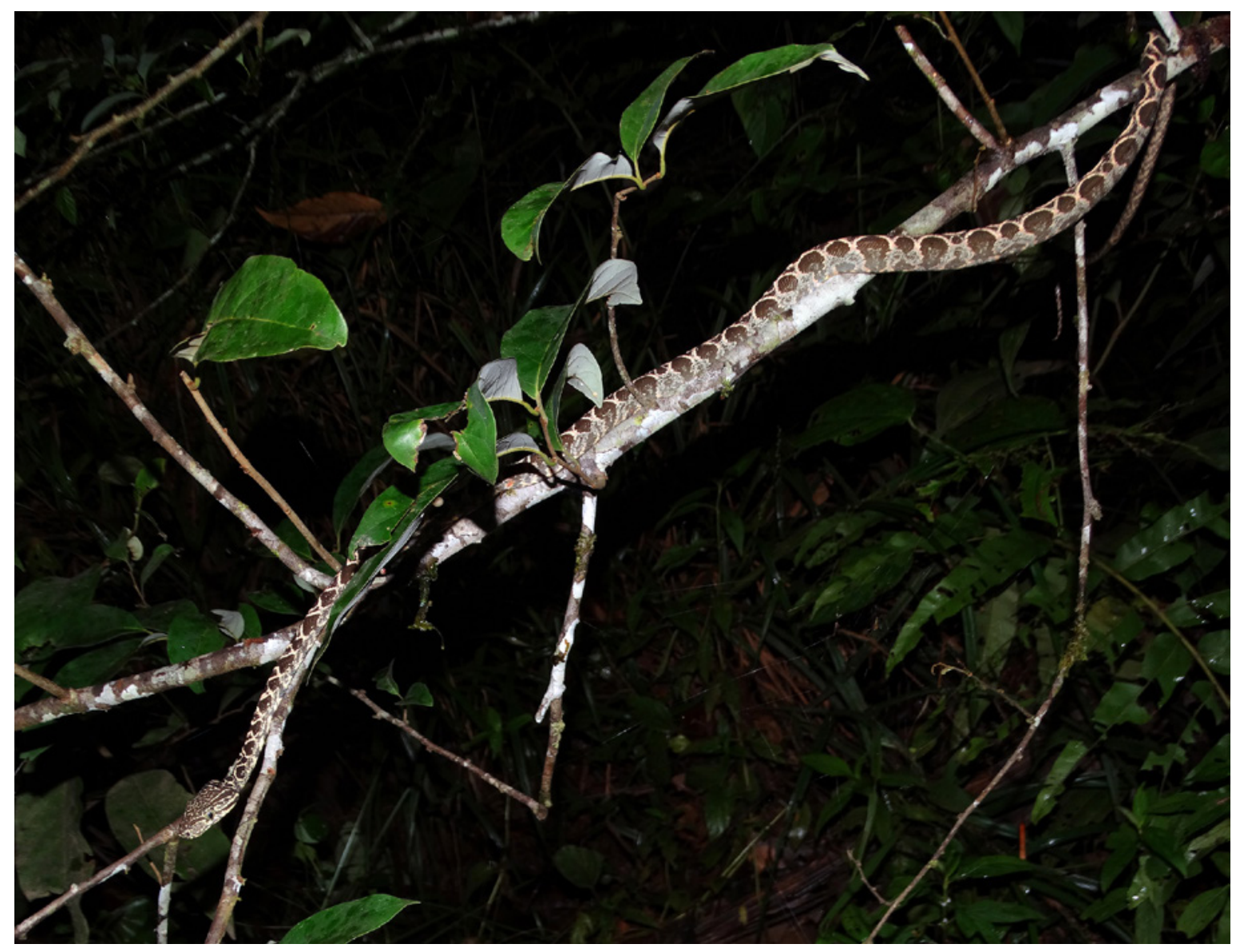

Fig. 8. An Amazon Treeboa (Corallus hortulanus) from Yasuni National Park, Ecuador, with an ellipsoidal gray pattern with pinkish edges. 


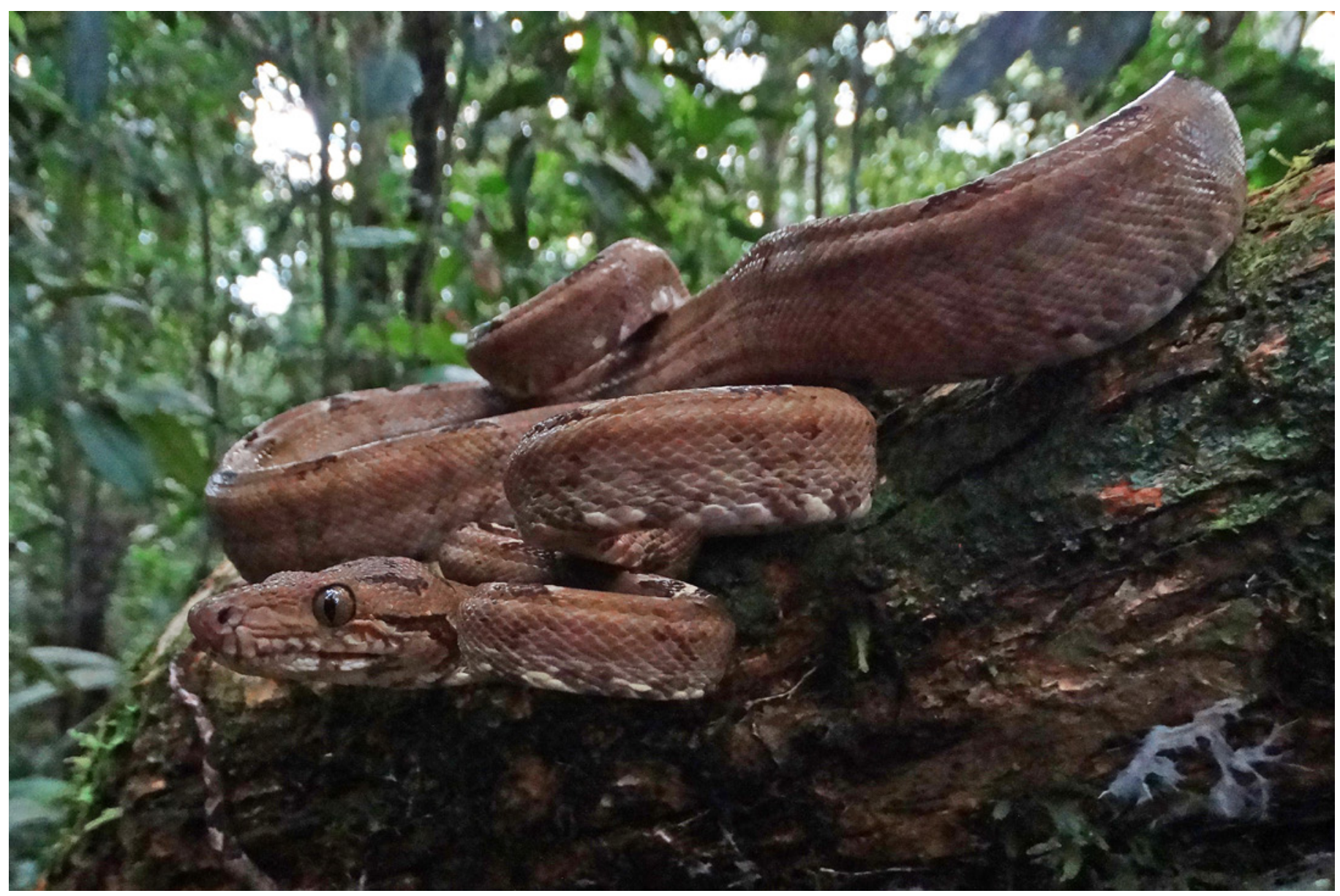

Fig. 9. An Amazon Treeboa (Corallus hortulanus) from Yasuni National Park, Ecuador, with a uniform pale-brown ground color and small, scattered $\mathrm{x}$-shaped middorsal marks.

als and the overall appearance is dark to light brown (Fig. 10). The posterior part of the body is darker, with light or yellow rhombs, and the tail is occasionally black with yellow marks (but never solid black as in Costa Rican snakes). The venter is almost always yellow to yellowish white and never checkered.

Activity.-Of 167 recorded encounters with C. ruschenbergeri in Los Llanos (many more unrecorded), 162 were at night, usually between 1830 and $2100 \mathrm{~h}$, while I was taking tourists on a boat for nocturnal wildlife safaris. In 16 years, I found only five individuals during the day; these were always coiled and hidden, never active. Two were in the transitional zone between the Llanos and the eastern Andean piedmont, where we took tourists rafting in the Acequias and Canaguá Rivers. These two snakes (or one snake seen twice, as both observations were in the same tree but months apart, and I was on a rafting boat without any possibility to stop and check) were sleeping in a branch hanging about $2 \mathrm{~m}$ high over the fast flowing Río Acequias in Barinas state. Our rafting boat passed under branch and boa, which remained completely motionless. Other observations were during the day in the Apure River and Caño Caiman, a small tributary. One instance involved a tail hanging outside a woodpecker nest, and the

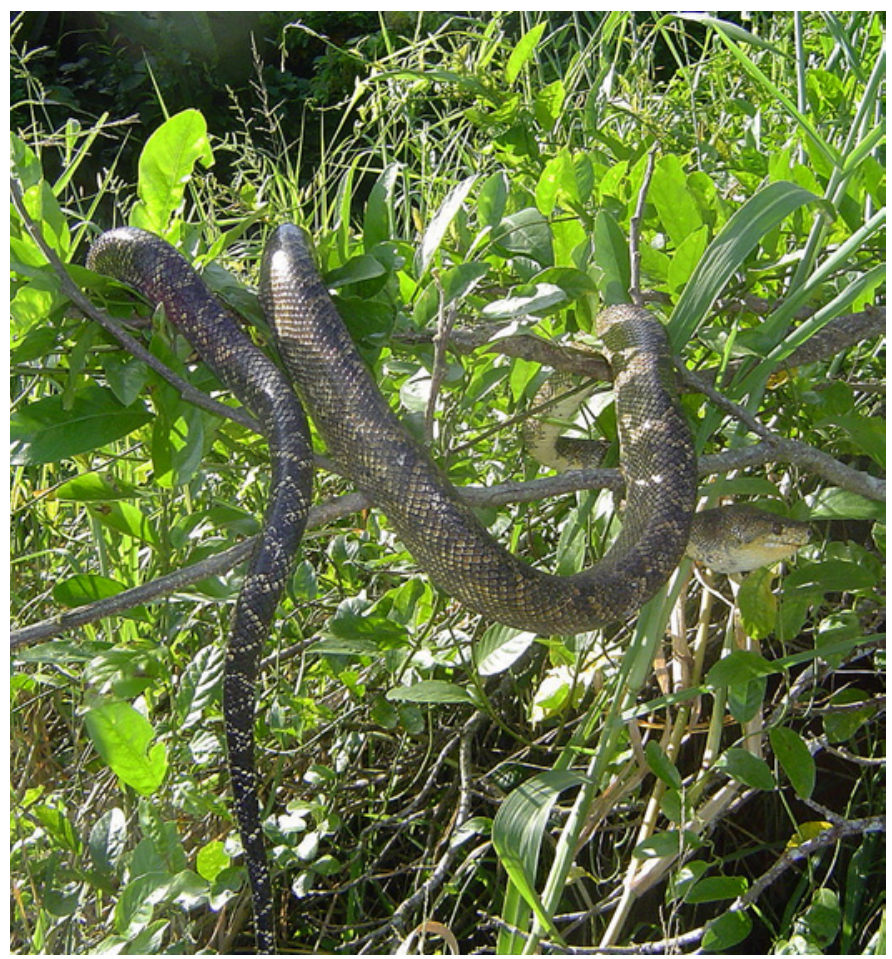

Fig. 10. A female Ruschenberger's Treeboa (Corallus ruschenbergerii) from Caño Caiman, San Vicente, Apure, Venezuela. 
other two snakes were coiled 10 to $15 \mathrm{~m}$ high in the canopy. A troop of monkeys was molesting one of the snakes (see below).

Of the 162 nocturnal observations, 117 were during the dry season and 45 during the rainy season. We did work more frequently during the dry season, but I am quite confident that seeing treeboas in the rainy season is more difficult as they are not restricted to the edge of the river but also forage in the flooded forest. In addition, the conditions during the rainy season (cloudy, even foggy or raining) do not facilitate detection. In contrast, during the dry season, treeboas appear to concentrate along the river's edge where they more easily find food and mates.

Reproduction.-At about 2000 h on 31 December 2005, in the gallery forest of the Río Apure close to the little village of San Vicente, I saw a number of eye reflections coming from a semi-isolated tree on the shore of the river. The tree, a small Samán (Samanea saman) about $10 \mathrm{~m}$ high but with a wide canopy, was connected to the contiguous forest vegetation by a small ( $3 \mathrm{~m}$ high) bush. On other nights on that same tree, I had found a Brazilian Porcupine (Coendou prehensilis), an Ocelot (Leopardus pardalis), a Collared Anteater (Tamandua tetradactyla), and on the ground below the tree the only Lancehead (Bothrops aff. atrox) I ever found in the deep Llanos. I am tempted to say that this tree was somewhat magical. But that night, the many eyes attracted my attention. I thought that perhaps some mammals (like opossums) or birds (like nightjars) were gathering for some reason, but never imagined that all those eyes belonged to treeboas. Seven in total! One large female about $180 \mathrm{~cm}$ long and six males. One male was mating, coiled over the female; two more were approaching aggressively and touching and tongue-flicking the female; two others were a few meters away but crawling slowly toward the female; and another was motionless about 5 $\mathrm{m}$ away and close to the low bush. Almost an arboreal equivalent of a mating ball, such as those described for Anacondas (Eunectes). As usual, I was with tourists and could not stop for more than a few minutes to observe the progress of the party. Since I have not since seen or read about anything quite like this, I cannot say if this was a common or extraordinary event. That night, I also observed three more treeboas on the return trip, resulting in my personal record of 10 boas in two hours.

I did not observe any aggressive interactions. However, one male treeboa captured almost two weeks later (11 January 2006) in the same tree had a very striking fresh wound (Fig. 11) that might or might not have been related to some conspecific interaction. Of course, it also might have been the result of an unsuccessful predatory attempt. During the rainy season (May-September), I have found very young snakes, usually high in the canopy and not easy to reach.

Potential Predators.-At dusk on 4 May 2005, during a boat trip on the Apure River, I saw a Laughing Falcon

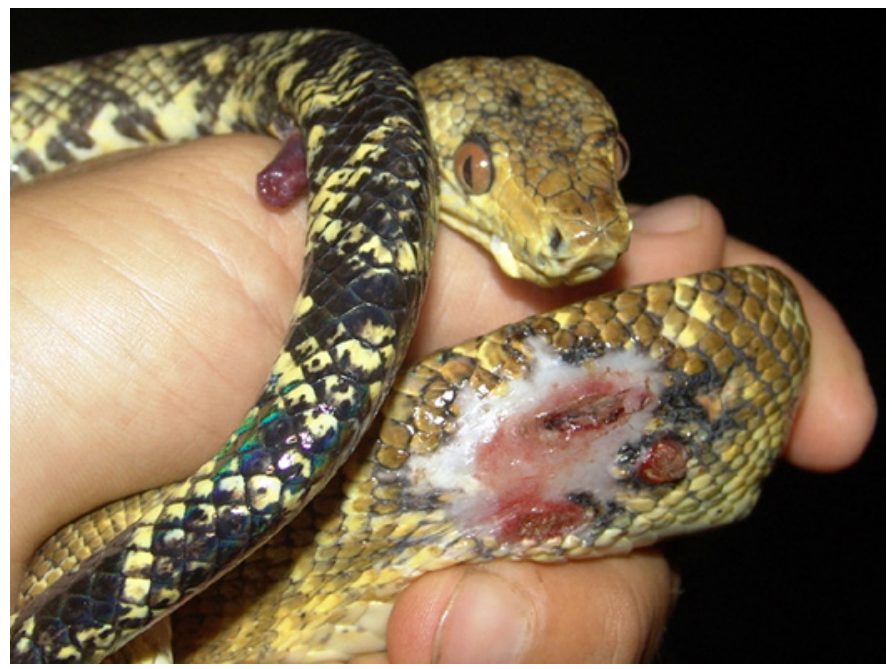

Fig. 11. A Ruschenberger's Treeboa (Corallus ruschenbergerii) from Río Apure, Apure, Venezuela. Note the everted hemipenis and a fresh wound that might have resulted from a conspecific interaction or a failed predation attempt.

(Herpetotheres cachinnans) obviously agitated while moving around a very high branch. With binoculars, I could see that it was molesting a large treeboa. I observed them for several minutes, but after sharing my binoculars with some tourists, I did not see if the snake escaped, but the falcon flew away with nothing in its claws.

During the day on 13 April 2007, on a small tributary of the Apure River, I saw a troop of very excited Capuchin Monkeys (Cebus olivaceus) chirping and shouting at a large treeboa coiled on a branch. Despite the antics of the troop of more than 14 monkeys, the boa remained coiled, although its head could be seen and the snake appeared to be quite alert and aware of the activity. One subadult male monkey hit the snake with a small branch. After several minutes, the monkeys lost interest and left the snake apparently unharmed.

Defense.-Several times, while handling C. ruschenbergerii in Los Llanos, boas, seeing no way out, wrapped themselves into a ball in my hands (such balling behavior also was reported by Henderson 2015; p. 238).

Feeding.-During all my encounters with C. ruschenbergerii in Los Llanos, I observed only one predatory event. At about $1900 \mathrm{~h}$ on 29 July 2005 , during the peak of the rainy season, with the river flooding the surrounding savanna, we saw a medium-sized boa constricting a medium-sized Green Iguana (Iguana iguana). We were unable to measure it without intervening. As we (the tourists and I) were navigating upriver, we returned to the site about one hour later and saw that the boa had almost completely swallowed the iguana (just a part of the iguana's tail emerging from the snake's mouth).

Another observation was interesting, but I cannot confirm that it consisted of an attempt at predation. On $17 \mathrm{March}$ 


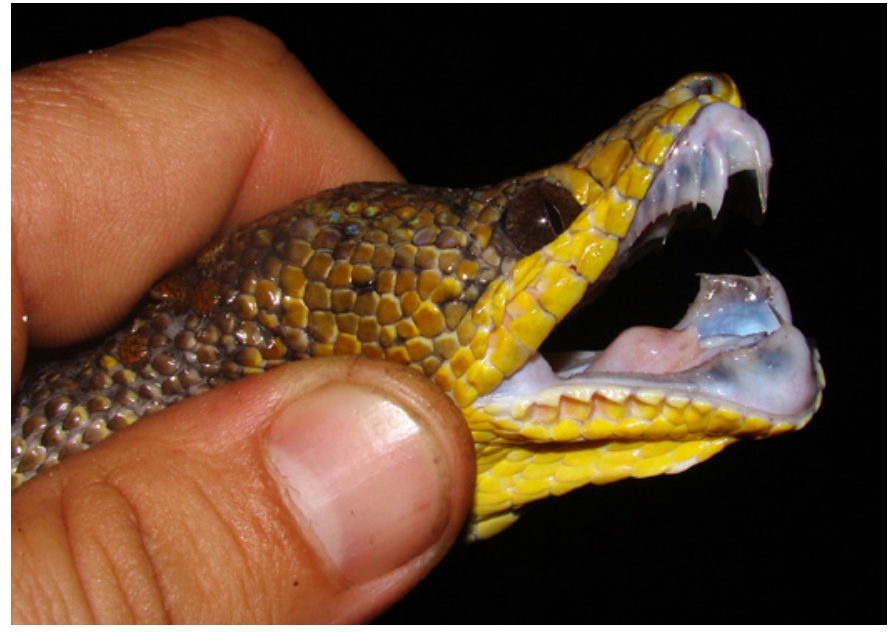

Fig. 12. A Ruschenberger's Treeboa (Corallus ruschenbergerii) from Puerto Concha, Zulia, Venezuela. Note the long agliphous teeth characteristic of treeboas.

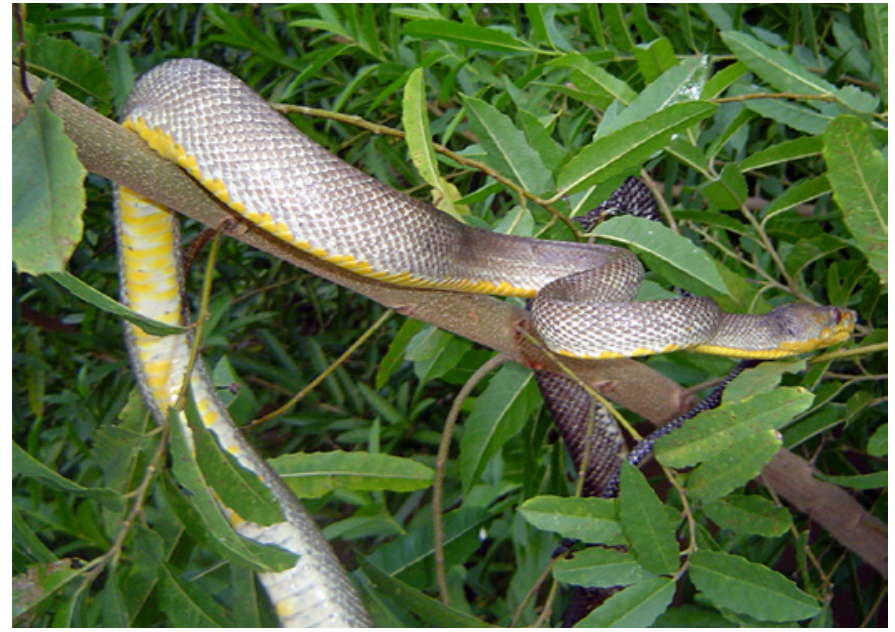

Fig. 13. A plain bluish-gray color phase in a Ruschenberger's Treeboa (Corallus ruschenbergerii) from Rio Catatumbo, Zulia, Venezuela.

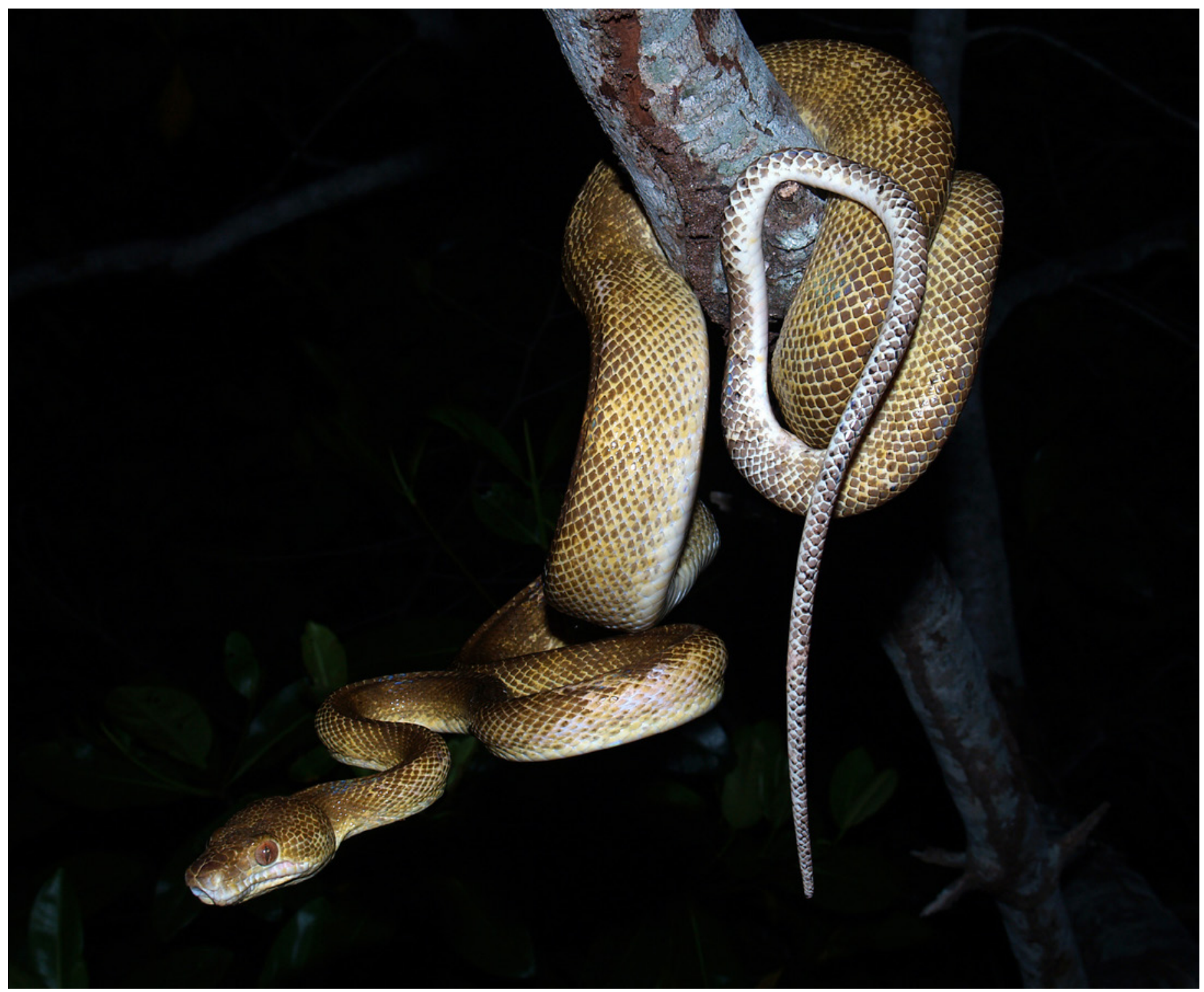

Fig. 14. A plain pale-brown color phase in a Ruschenberger's Treeboa (Corallus ruschenbergerì) from Puerto Concha, Zulia, Venezuela. Photograph by Alan Highton. 


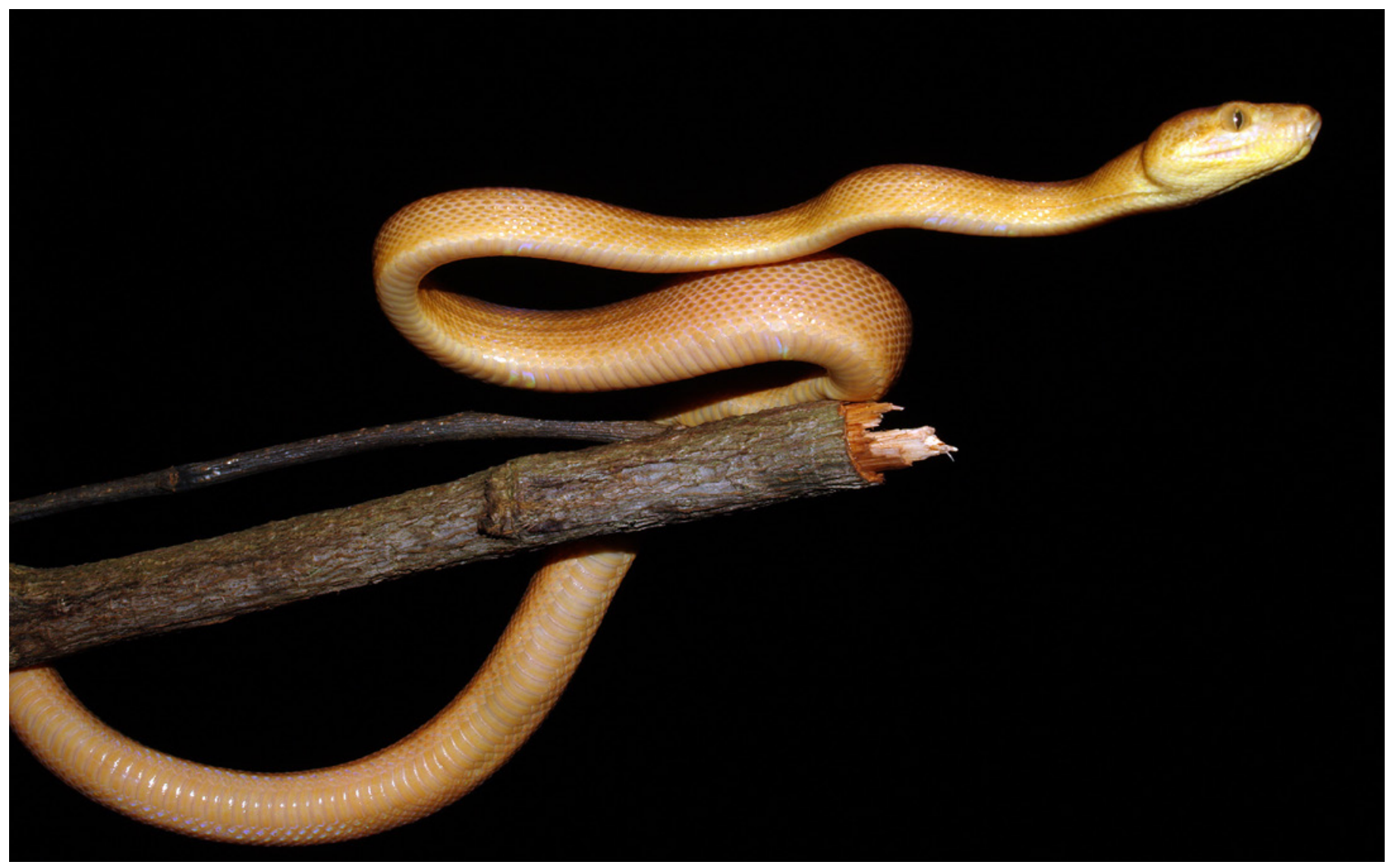

Fig. 15. A plain yellowish-brown color phase in a Ruschenberger's Treeboa (Corallus ruschenbergerii) from Puerto Concha, Zulia, Venezuela. Photograph by Alan Highton.

2004, the boatman directed the boat toward several eyeshines along the shore of the Apure River. At that time of year, we commonly saw a number of recently hatched Spectacled Caimans (Caiman crocodilus) about $25 \mathrm{~cm}$ long, in close proximity, and often attracting predators (despite the mother usually being nearby). A treeboa about $120 \mathrm{~cm}$ long was on a low branch less than $50 \mathrm{~cm}$ from the shore and about $1 \mathrm{~m}$ from the closest caiman hatchling. I did not realize the treeboa was there until I came closer to capture some of the caimans to show to the tourists. Of course, our approach frightened the little caimans and I am still not sure if the boa had been pursuing them or if its proximity was a mere coincidence.

Interaction with humans.-When I first saw Corallus ruschenbergerii (always at night using headlamps from a boat), I was eager to approach and catch one. The main obstacle I discovered was the opposition of the boatmen. All Llaneros were, without exception, terrified by treeboas. The "Macaurel' (local name for treeboas) in northern Venezuela is considered to be highly venomous and is to be avoided at all times. Even if I asked as a special favor for a slow approach in order not to disturb the animal, boatmen (usually fishermen) always denied the request with fear in their eyes. I took advantage of a single capture to show them that Macaureles were not venomous; for that, of course, I needed to allow one to bite me. I was in the front of the long boat with several tourists and my boatman at the prow was so scared that he obvi-

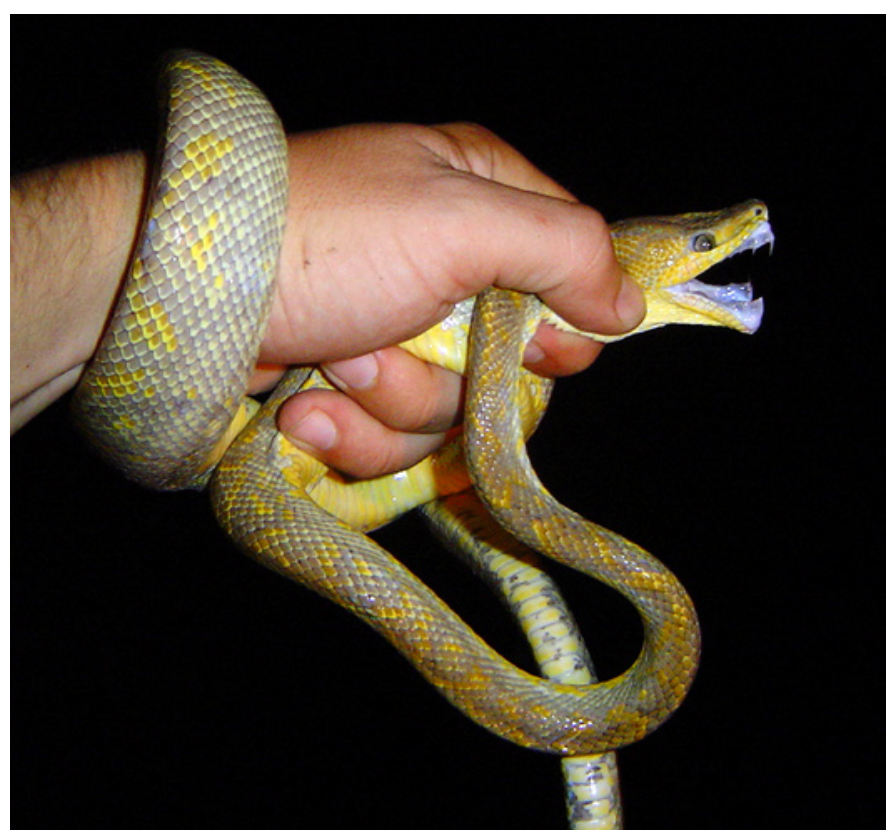

Fig. 16. A gray Ruschenberger's Treeboa (Corallus ruschenbergerii) with faint yellow marks from Puerto Concha, Zulia, Venezuela. 


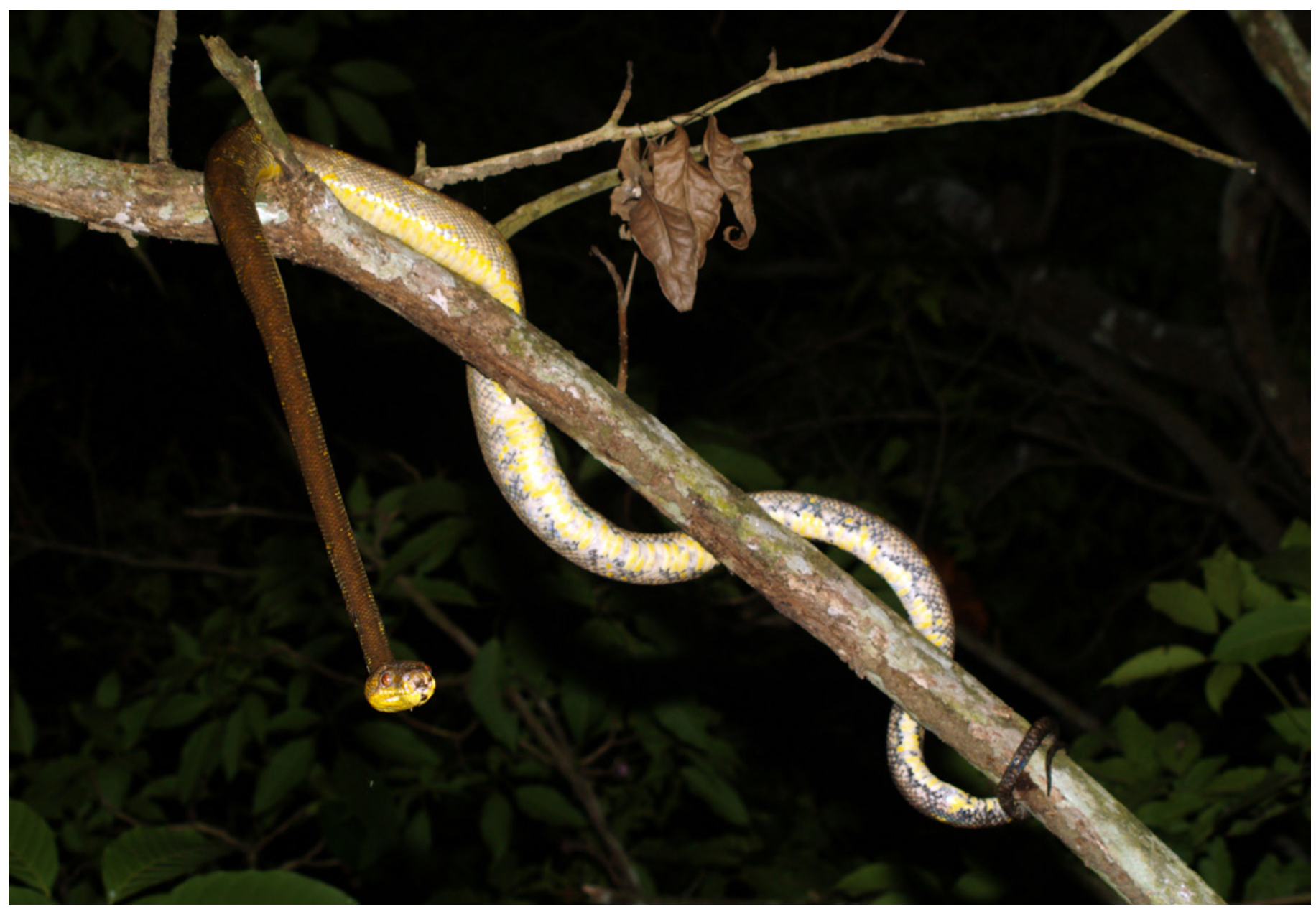

Fig. 17. A Ruschenberger's Treeboa (Corallus ruschenbergerii) from Puerto Concha, Zulia, Venezuela. Photograph by Alan Highton.

ously wanted to escape. I explained to the tourists in English the demonstration I was going to do and asked them to pay attention to Carlos's (the boatman) face when the snake bit me. Of course, he was so worried that he could not look. The boa struck as expected, and my hand started to bleed a little. I explained to him that nothing was going to happen to me. Then I took the snake back to our lodge in order to show the rest of the town how harmless the boas actually are. My intention was to show the fishermen that they should not be scared and to stop killing these snakes. I called some of my llanero friends in the village and asked them to gather around me. I had the snake in a bag. I released it onto the floor, and everyone there was scared and moved back a few meters. I caught it at midbody with my bare hand, anticipating another strike and bite, which arrived soon. In the meantime, I explained to the people that these snakes, despite their long teeth, are not venomous (Fig. 12), and that they are related to common Boa Constrictors (Boa constrictor), which they know are not venomous. More than one person exclaimed that I was a sorcerer, and that I had some contra (like a spell against venom). Many of the people who were present left that night worried about me, and many came by the next day to see if I was alive
— and, of course, I was! They were confused. With time, and because many of these fishermen ran boats for my tours, they all learned that Macaureles are not venomous. The same situation also arose in Costa Rica, especially along the mangrove areas, where this snake is known as "Manglera." People from those areas are terrified by treeboas, but it was a little easier here than in Venezuela to convince a few of the locals that these snakes were not venomous.

\section{Maracaibo Lake Basin}

Pattern.-The first thing you notice when you see a treeboa from the Maracaibo Lake area is that they look very different from those from Los Llanos. They lack the common diamond-like pattern of other populations or, at most, it is very faint and diffused. The Maracaibo pattern is variable in color but usually uniform. Individuals can be bluish gray (Fig. 13), pale (Fig. 14) to yellowish brown (Fig. 15) with no marks at all or occasionally with some faint yellow (Fig. 16) or black (Figs. 17 and 18) pattern elements that normally do not form diamonds. I found that the proportion of individuals with a diamond-like pattern (Fig. 19) at the Maracaibo Lake basin is as low as $10 \%$, but even when present, it is always very faint. 


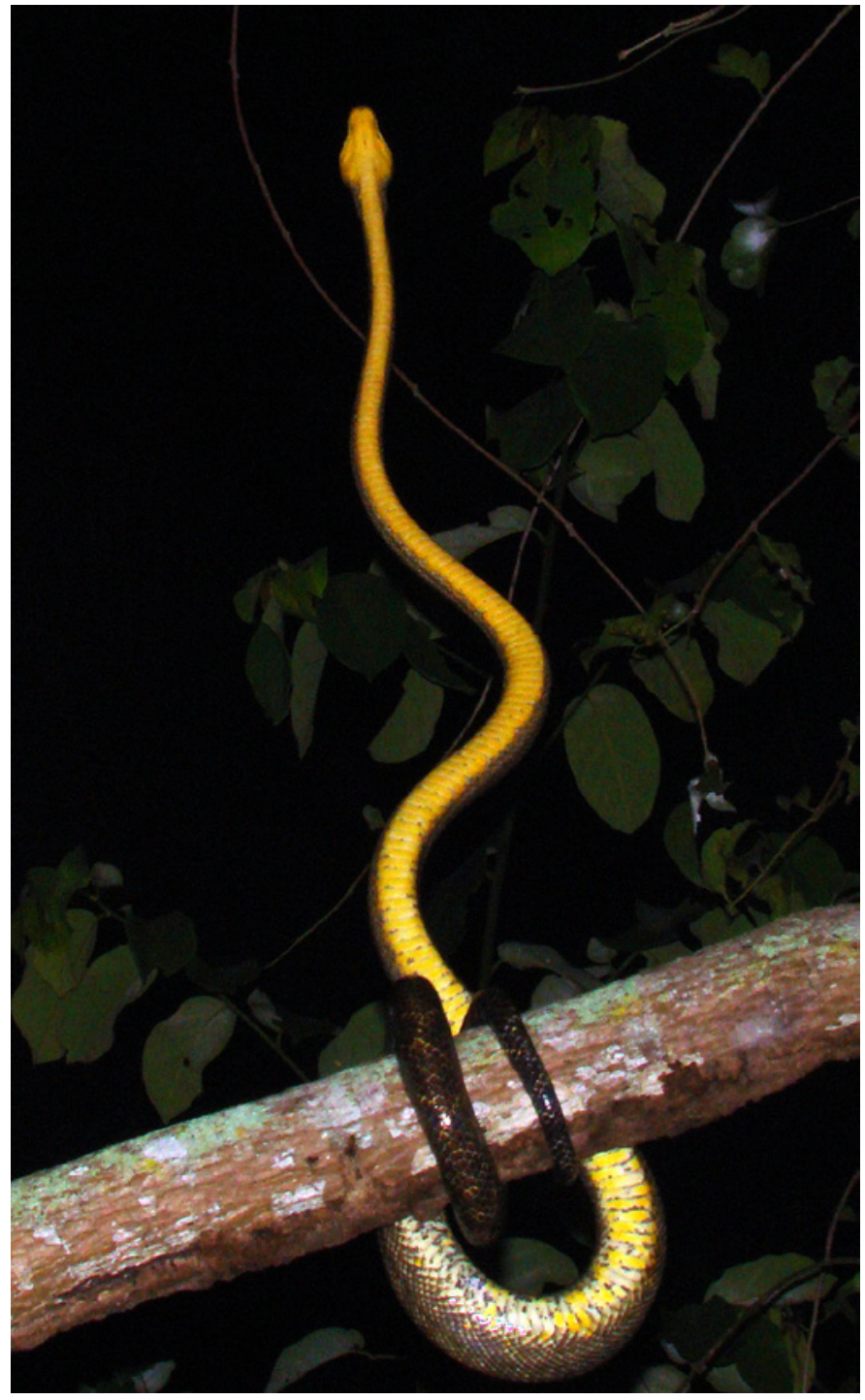

Fig. 18. A Ruschenberger's Treeboa (Corallus ruschenbergerii) from Puerto Concha, Zulia, Venezuela, seeking to escape into the crown. Note the yellow venter.

The belly can be immaculate yellow (Fig. 18), white (Fig. 14), pale orange (Fig. 15), yellow with white intrusions (Fig. 17), or even with some black checkering on the flanks (Fig. 17).

Natural history.-During more than 50 tours to the southwestern edge of the Maracaibo Lake, I took tourists through mangrove canals to observe wildlife, both during the day and night. One of the highlights during the night-time boat trips was, of course, to spot and capture Brown Caimans (Caiman crocodilus fuscus) and treeboas, which I usually did easily. Unfortunately, I did not record as much detailed data of those encounters as in Los Llanos. Consequently, I cannot provide an accurate count of those encounters, but I would estimate that I found about 50 snakes (a mean of one per night; sometimes as many as 4 , but sometimes none). The main habitat in the area is mixed mangrove forest along natural and artificial canals used by local fishermen to reach the lake.
I observed two feeding events, both adult boas that had captured adult Common Basilisk lizards (Basiliscus basiliscus), one almost swallowed, the other being constricted. These observations are similar to those cited by Henderson (2015).

I also saw a medium-sized boa (around $120 \mathrm{~cm}$ ) crawling near a group of sleeping Smooth-billed Anis (Crotophaga ani), but during the 10-minute observation (I had to continue the tour) the boa stopped and tongue-flicked, maybe deciding whether to continue or to abandon an attempt on such large prey.

On many occasions, both in Los Llanos and the Maracaibo Lake Basin, I have seen C. ruschenbergerii with external parasites, almost always ticks and, less frequently, mites (Arachnida: Acarina). A few of the snakes were so parasitized that survival seemed unlikely. One captured boa had eight ticks on its neck that looked as if they had caused some problems for the snake when shedding (Fig. 20).

One night in May 2005, people from the Universidad de Los Andes of Mérida at La Vueltosa Dam (Tachira state) and I captured an adult male treeboa $(135 \mathrm{~cm})$, light brown with faint diamonds, crossing a road in deciduous forest on a rainy night. That locality is in the southeastern versant of the Andes in the direction of the Los Llanos region.

\section{Costa Rica}

I currently live on the southern Pacific Coast of Costa Rica, well within the natural distribution of Corallus ruschenbergerii. Although I have found many treeboas during the past five years, I have never encountered them in the same abundance as in the Venezuelan Llanos. Costa Rican treeboas occur in two main microhabitats, mangrove swamps along the rivers that drain into the Pacific, where they are known as manglera (= a mangrove inhabitant) and where they appear to reach a greater abundance than in the lowland evergreen rainforests to elevations of about $500 \mathrm{~m}$ asl. The latter habitat covers the majority of the area between the Carara National Park and Punta Burica at the extreme southern tip of Costa Rica, and is also the main habitat in the immediate surroundings of my home. As I had never seen C. ruschenbergerii in Venezuelan rainforests (see however the new distributional record below), I did not expect to encounter the species here (assuming that they occurred only in coastal mangrove forests). However, I have seen several individuals in both natural and anthropogenic situations. These treeboas commonly forage for rodents and bats in the roofs of houses. One juvenile about $80 \mathrm{~cm}$ in length was in my kitchen (Fig. 21), which is open to the forest; I released it along a nearby creek. During my nocturnal walks, I have found only two active treeboas. One was very high (about $20 \mathrm{~m}$ ) in a solitary tree, where I previously had seen roosting Chestnut-mandibled Toucans (Ramphastos swainsonni). It was a large snake, nearly $2 \mathrm{~m}$ in length, and was slowly descending the trunk, apparently uninterested in investigating the large birds (too large perhaps). The other 


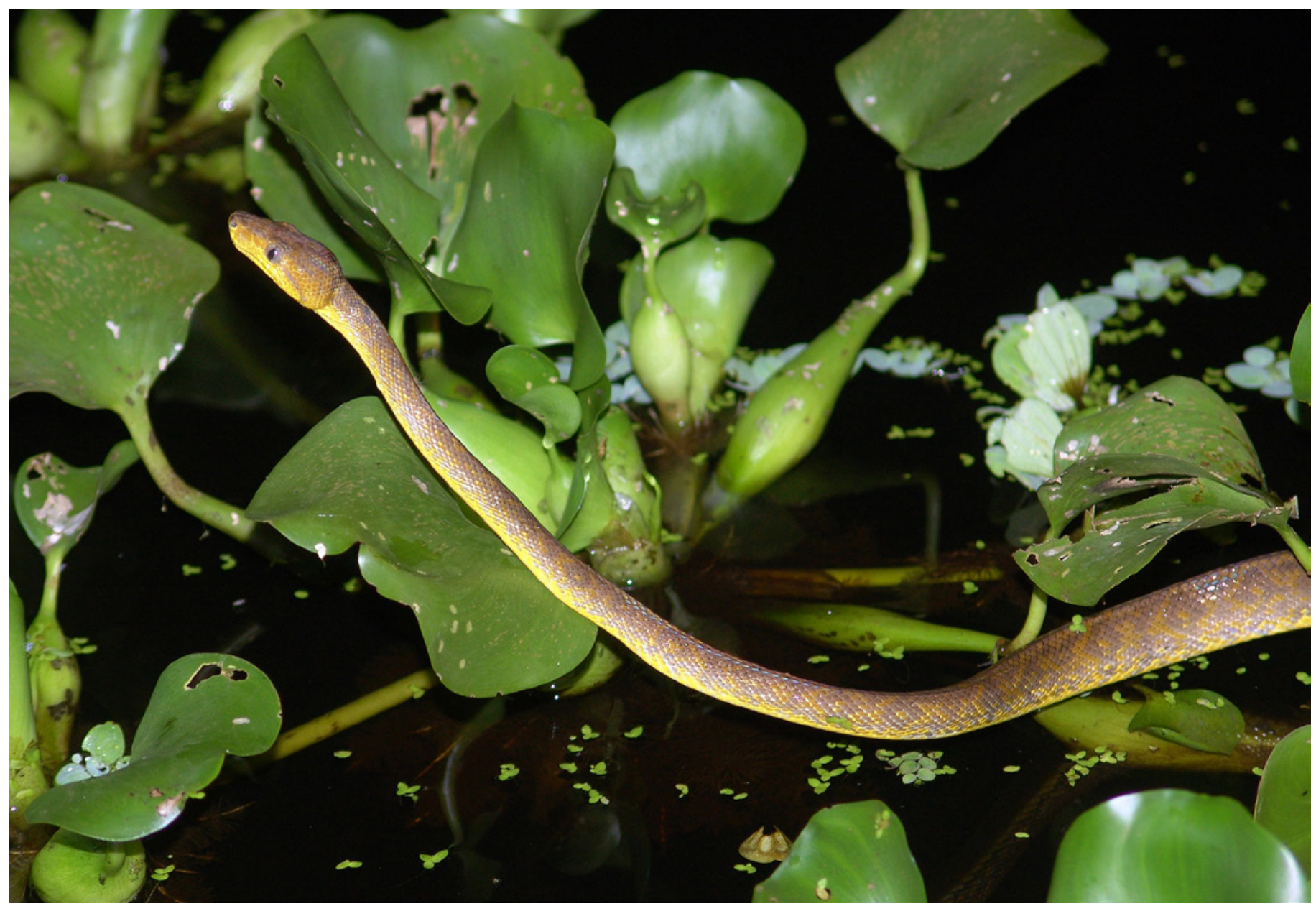

Fig. 19. A Ruschenberger's Treeboa (Corallus ruschenbergerii) from Puerto Concha, Zulia, Venezuela, with a very faint diamondlike pattern on its flanks. The treeboa was not originally in the water, where it was released after taking some photographs.

boa was in a colony of Montezuma Oropendolas (Psarocolius montezuma), which are recent invaders of the southern Pacific Coast, near Dominical, Puntarenas. Such colonies are large and the Oropendolas are loud and aggressive. At night, however, these birds sleep inside their nests and the treeboa of medium size (about $1.4 \mathrm{~m}$ ) was crawling from nest to nest but not entering any, perhaps recognizing that they were inhabited by large, aggressive birds.

I have seen many treeboas during the day at the Sierpe mangrove swamps, thanks to the incredible sight and experience of boatmen, who recognized them from a distance when coiled and resting during morning hours (Fig. 22). A final observation occurred in a small, deep canyon of the Morete River (San Josecito, Uvita de Osa area) during a daytime river tour near my house. While returning to the starting point of the two-hour tour, I noticed a King Vulture (Sarcoramphus papa) inspecting something on a low branch. Obviously, something dead was nearby. I had no camera, but approaching slowly to observe the rather magnificent vulture, I saw Turkey Vultures (Cathartes aura) and Black Vultures (Coragyps atratus) around a carcass of a large female treeboa (probably about $2 \mathrm{~m}$ in length, although one-third of the body was missing),

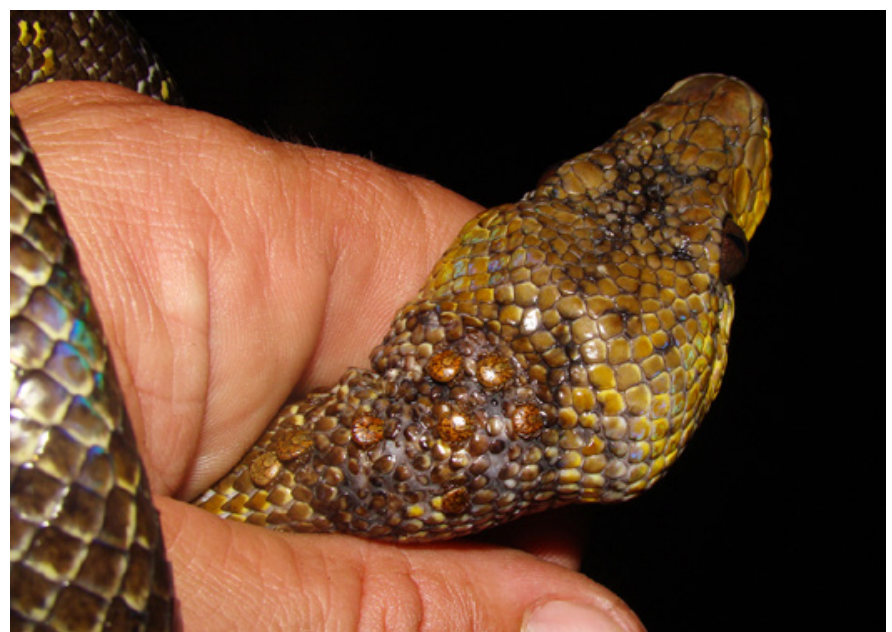

Fig. 20. A Ruschenberger's Treeboa (Corallus ruschenbergerii) from Puerto Concha, Zulia, Venezuela, infested with ticks.

already eaten to the bones. The carcass was not smelly, so this had apparently been a very recent death. In addition, the head, which the vultures had left intact, was in perfect condition. I wondered if this snake was already dead when I passed the first time and I did not see it, or if it was killed by the 


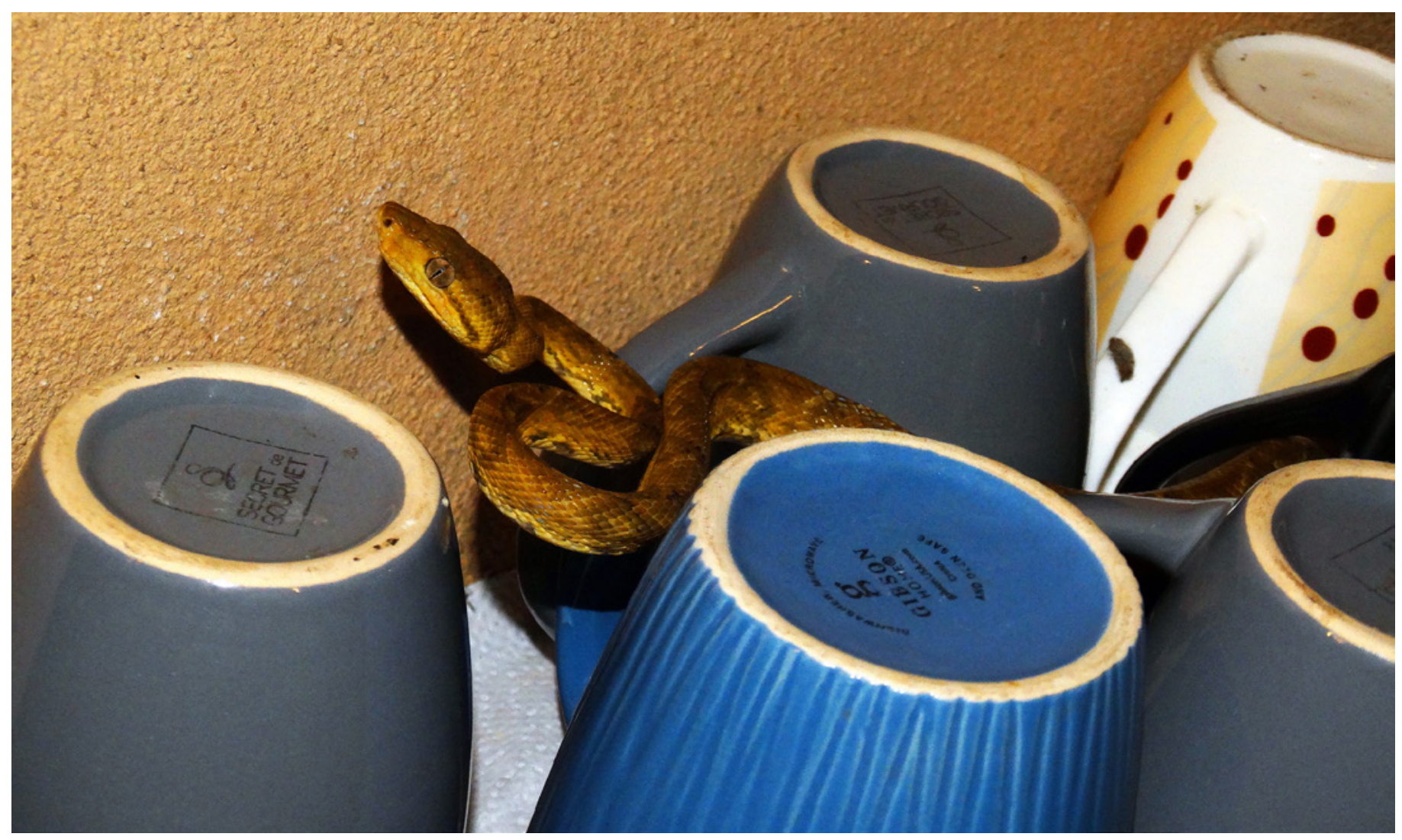

Fig. 21. A subadult Ruschenberger's Treeboa (Corallus ruschenbergerii) found in the author's kitchen in San Josecito, Uvita de Osa, Puntarenas, Costa Rica. It was later released in the vicinity of a nearby stream.

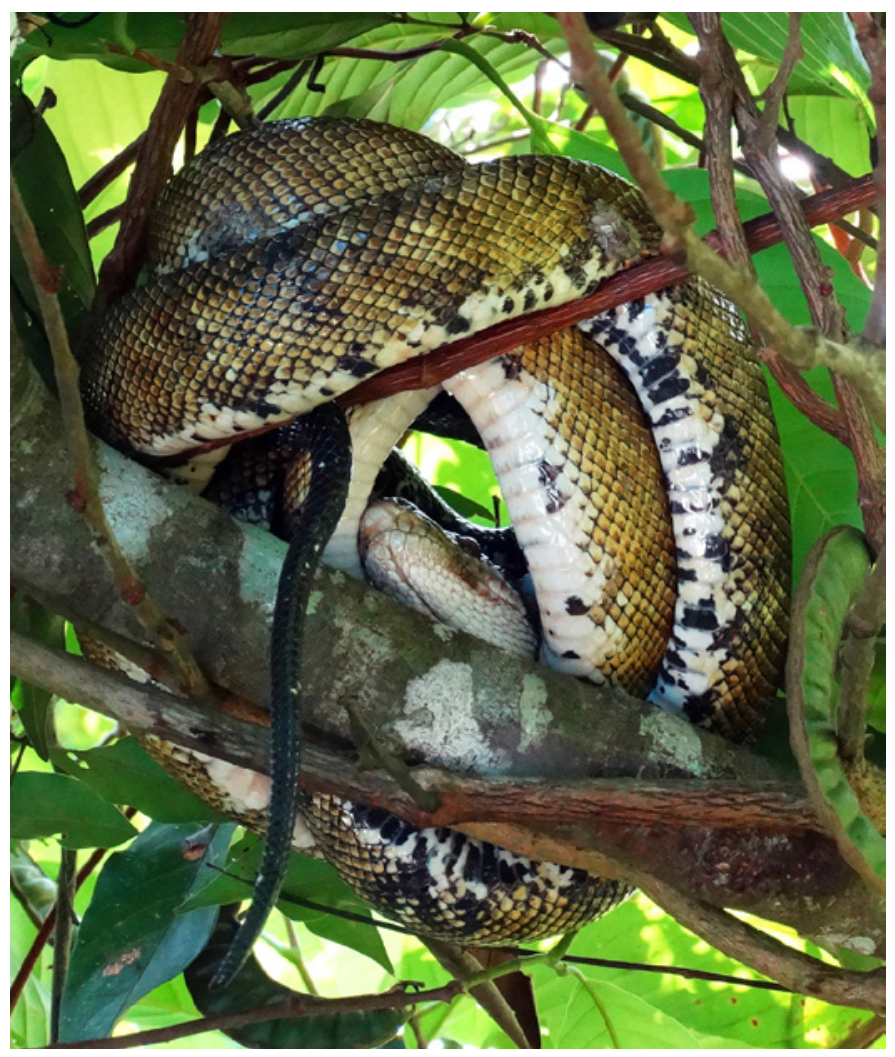

Fig. 22. A coiled adult Ruschenberger's Treeboa (Corallus ruschenbergerii) from Sierpe de Osa, Puntarenas, Costa Rica, resting during daylight hours. vultures or another raptor and brought to the river. I still do not understand why they had not eaten the head (not even the eyes).

Patterns typical of the Venezuelan Llanos, Maracaibo Basin, and other sites are quite different than those of Costa Rican treeboas. I have never seen one of the latter without a striking black tail, completely black or flecked with small white spots (Fig. 23). Tails of Venezuelan treeboas are never entirely black. This made me wonder if Central American treeboas are indeed different from those in northern South America. A close herpetofaunal connection exists between the Maracaibo Basin and Central America, with several Central American species reaching the eastern biogeographic limits of their ranges at this large basin; see Barrio (2001) for the Truando Toad (Rhaebo haematiticus); Infante-Rivero et al. (2006) for the leaf frog, Phyllomedusa venusta; Manzanilla et al. (1999) for the Pacific Long-tailed Snake (Enulius flavitorques); Rojas-Runjaic and Infante-Rivero (2008) for the South American Forest Racer (Dendrophidion percarinatum); and Rojas-Runjaic et al. (2008) for the Graceful Brownsnake (Urotheca fulviceps); just to mention a few. Colston et al. (2013) demonstrated that the genetic distance between Costa Rican and eastern Venezuelan specimens is low, despite including no snakes from the Maracaibo Basin in their analyses. That would suggests that, despite different pat- 


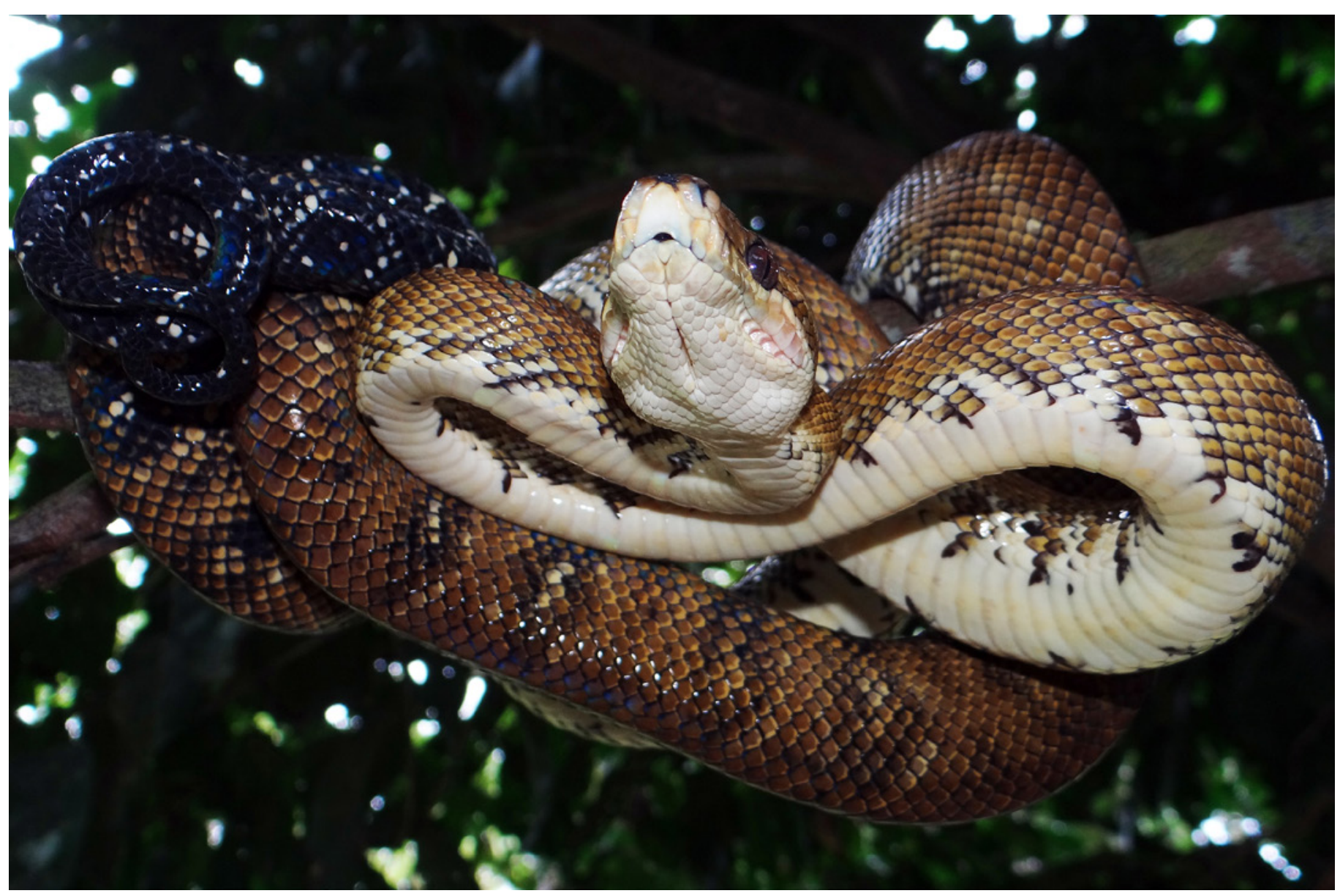

Fig. 23. A typical adult pattern in a Ruschenberger's Treeboa (Corallus ruschenbergerii) from the Pacific versant of Costa Rica. Note the white belly and the black tail speckled with white. Photograph by the author, courtesy of Quetzal Dwyer.

terns, $C$. ruschenbergerii is a conservative species that probably expanded its range recently from South America into Central America via the Panamanian isthmus.

Finally, the cloacal discharge of musk is a common defensive behavior of essentially all species of Corallus (although I have never been victimized by either $C$. caninus or $C$. batesii). This discharge is accompanied by a deeply offensive odor that makes you wonder why you still bother to capture these snakes — although, as Henderson (2015) stated, some other snakes might generate even more offensive odors. Cat-eyed Snakes (Leptodeira), for example, are small but really stinky, and anacondas (Eunectes spp.) are large aquatic boids that you will remember both for the bite and their particularly nasty "eau de serpent" — but treeboas clearly rank among the most prone to use their cloacal contents for defense. Nasty as it is, I still catch treeboas, and despite the obvious assumption that evolved behaviors must work, I wonder how effective this strategy can be in the face of determined predators like felines, mustelids, or raptors.

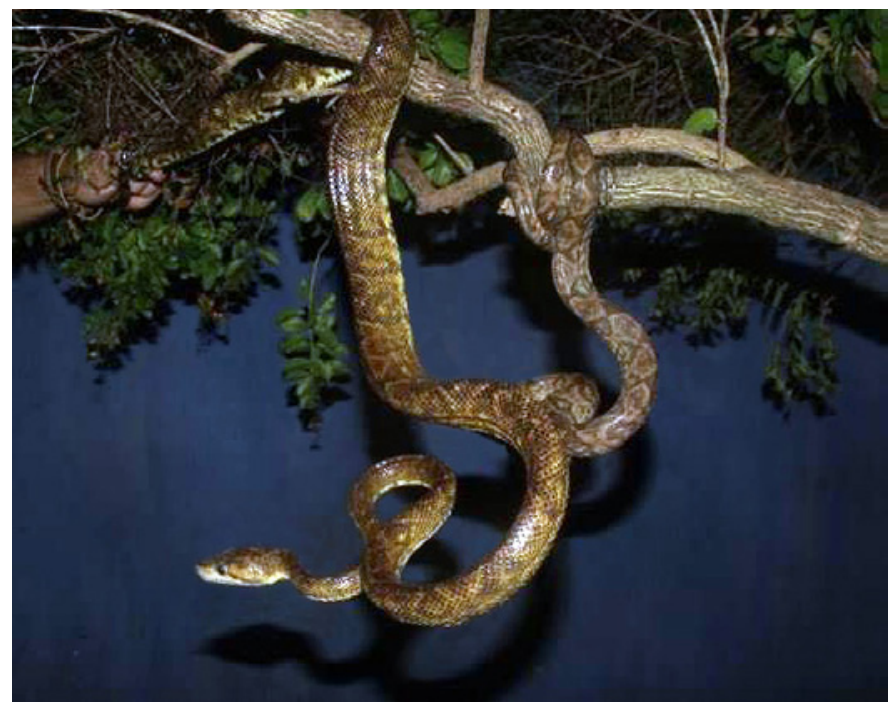

Fig. 24. A large adult Ruschenberger's Treeboa (Corallus ruschenbergerii) from El Playón, Río Caura, Estado Bolívar, Venezuela, found deep in an Orinoquian rainforest and microsympatric with Amazon Treeboas (C. hortulanus). Photograph by Daniel Calcaño. 


\section{New Distributional Record for Corallus ruschenbergerii in Sympatry with $C$. hortulanus}

\section{Calcaño and C.L. Barrio-Amorós}

Corallus ruschenbergerii is known mainly from the Llanos (gallery and dry tropical forest in a savanna environment) and in coastal mangrove forests. It generally is not considered a rainforest species, at least not in Venezuela, although it is present (but scarce) in lowland coastal rainforests in the states of Aragua, Carabobo, and Miranda. Daniel Calcaño (in litt., 27 January 2016) sent to César Barrio-Amorós a photograph (Fig. 24) of an adult C. ruschenbergerii taken at El Playón, Río Caura, Estado Bolívar (6¹9’37”N, 64³1'43”W, 55 m asl), in deep Orinoquian rainforest. Calcaño informed me that during several nights looking for eyeshines along the river, he encountered $10 C$. hortulanus for each $C$. ruschenbergerii. Henderson $(2002,2015)$ had maintained that $C$. hortulanus and $C$. ruschenbergerii are sympatric along the southern border of the Orinoco (corresponding in Venezuela to Amazonas and Bolivar States), but this needed verification. This is the first documented southern Orinoco rainforest locality where both species have been encountered in microsympatry.
A comparable observation occurred when Fernando Rojas-Runjaic, Santiago Castroviejo, and Barrio-Amorós found a $C$. ruschenbergerii in a vertical rotten log near Puerto Ayacucho, Amazonas state (July 2010; Fig. 25), surrounded by savanna and very close to rainforest habitats where $C$. hortulanus is common. That $C$. ruschenbergerii had a mainly plain pattern, beige with a few irregular dark dorsal markings and an ivory-white venter. The same night we saw $C$. hortulanus in nearby rainforest.

\section{Acknowledgments}

During the years, many friends and colleagues have accompanied me in my search for snakes. Listing only those who were with me on those occasions when I encountered Corallus is difficult, and I apologize in advance for any omissions. In Venezuela, I thank Alan Highton, Roger Manrique, Tom Evenue, Daniel Calcaño, Andrés Chacón, Amelia Díaz de Pascual, Iñigo Narbaiza, Oscar Vergara, Carlos Güiza, Luis Scott, Juan Pablo Diasparra, Celsa Señaris, and Fernando Rojas-Runjaic. In Costa Rica, I thank Gerardo "Boa” Zamora, Alejandro Arteaga, Lucas Bustamante, Paolo Escobar, and Quetzal Dwyer. In Ecuador, I thank Lucas Bustamante, Jaime Culebras, Alejandro Arteaga, Guillem Chacón, and

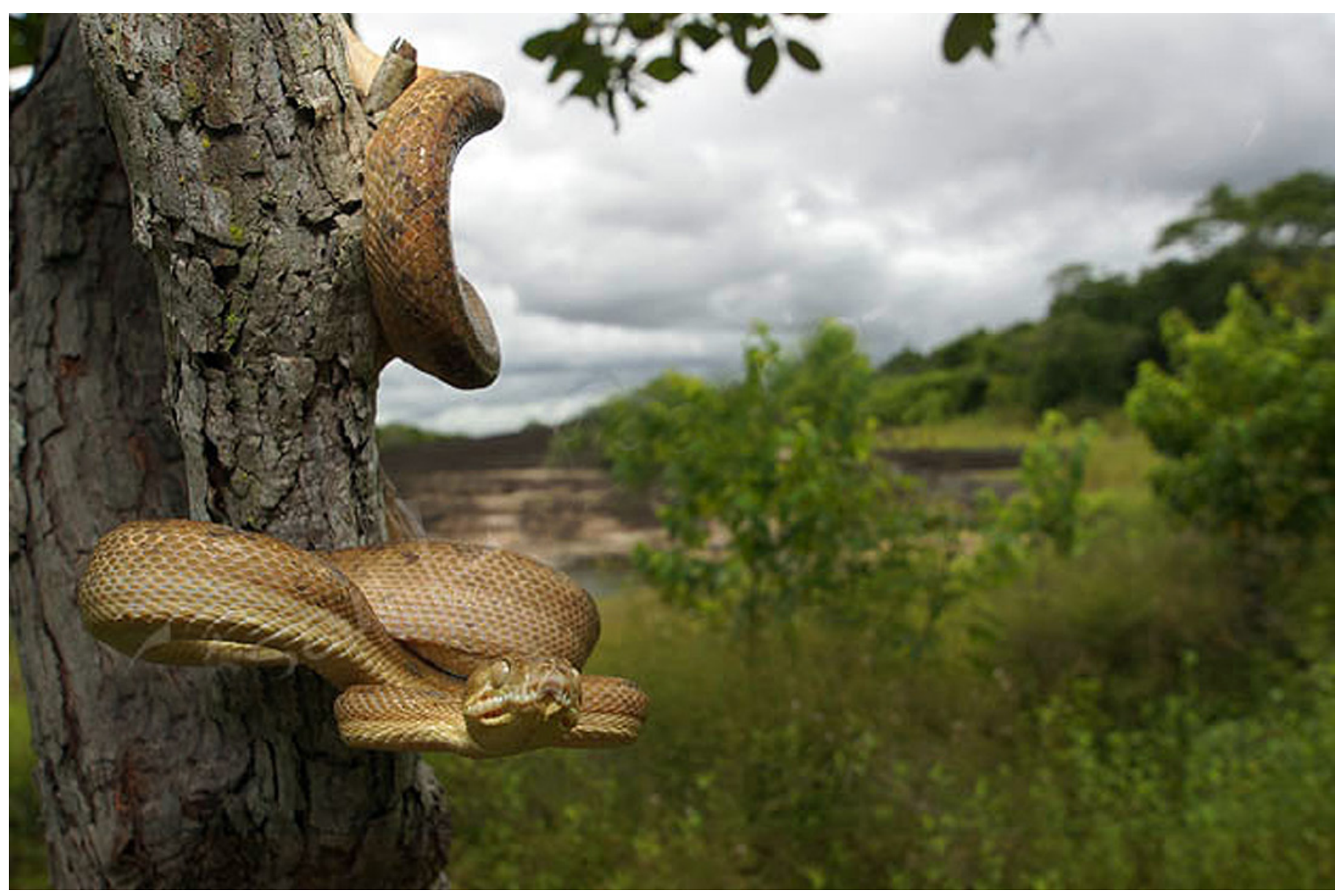

Fig. 25. A Ruschenberger's Treeboa (Corallus ruschenbergerii) from Puerto Ayacucho, Amazonas, Venezuela, macrosympatric with Amazon Treeboas (C. hortulanus). 
Darwin Núñez. In Perú, Rainer Schulte and Antonio Salas facilitated the search for different Amazonian species. I especially thank Robert "Boa Bob" Henderson for comments and the improved English in the last version of this manuscript.

\section{Literature Cited}

Barrio-Amorós, C.L. 2005. Fantastic herping in Venezuela's Guayana. Reptiles Magazine 13(11): 50-59.

Barrio-Amorós, C.L., T. Barros, and J.C. Páez. 2001. Geographic distribution: Bufo guttatus. Herpetological Review 32: 112.

Barrio-Amorós, C.L., C. Brewer-Carías, and O. Fuentes. 2011. Aproximación preliminar a la herpetocenosis de un bosque pluvial en la sección occidental de la Sierra de Lema, Guayana Venezolana. Revista de Ecología Latinoamericana 16: $1-46$.

Colston, T.J., F.G. Grazziotin, D.B. Shepard, L.J. Vitt, G.R. Coll, R.W. Henderson, S.B. Hedges, S. Bonatto, H. Zaher, and F.T. Burbrink. 2013. Molecular systematics and historical biogeography of tree boas (Corallus spp.). Molecular Phylogenetics and Evolution 66: 953-959.

Henderson, R.W. 2002. Neotropical Treeboas: Natural History of the Corallus hortulanus Complex. Krieger Publishing Co., Malabar, Florida.
Henderson, R.W. 2015. Natural History of Neotropical Treeboas (genus Corallus). Edition Chimaira, Frankfurt am Main, Germany.

Manzanilla, J., A. Mijares-Urrutia, R. Rivero, and M. Natera. 1999. Primer registro de Enulius flavitorques (Cope, 1871) (Serpentes: Colubridae) en Venezuela. Caribbean Journal of Science 35: 150-151.

McDiarmid, R.W. and A. Paolillo. 1988. Herpetological collections: Cerro de la Neblina, pp. 667-670. In: C. Brewer-Carías (ed.), Cerro de La Neblina, resultados de la expedición 1983-1987. Fundación para el Desarrollo de las Ciencias Físicas, Matemáticas y Naturales (FUDECI), Caracas, Venezuela.

Natera-Mumaw, M., L.F. Esqueda González, and M. Castelaín-Fernández. 2015. Atlas serpientes de Venezuela. Una visión actual de su diversidad. Dimacofi Negocios Avanzados S.A., Santiago, Chile.

Pritchard, P.C.H. and P. Trebbau 1984. The Turtles of Venezuela. Society for the Study of Amphibians and Reptiles Contributions to Herpetology Number 2, Oxford, Ohio.

Rojas-Runjaic, F.J.M. and E.E. Infante-Rivero. 2008. First record of the forest racer snake Dendrophidion percarinatum (Cope, 1893) (Serpentes: Colubridae) from Venezuela. Caribbean Journal of Science 44: 128-130.

Rojas-Runjaic, F.J.M., M. Natera-Mumaw, and E.E. Infante-Rivero. 2008. Reptilia, Squamata, Colubridae, Urotheca fulviceps: Distribution extension. Checklist 4: 431-433. 